\title{
THE COMBINED EFFECT OF SURFACE CHEMISTRY AND FLOW CONDITIONS ON STAPHYLOCOCCUS EPIDERMIDIS ADHESION AND ica OPERON EXPRESSION
}

\author{
Antigoni Foka ${ }^{1, \#}$, Maria G. Katsikogianni ${ }^{2, \#}$, Evangelos D. Anastassiou ${ }^{1}$, Iris Spiliopoulou ${ }^{1}$ and Yannis F. Missirlis ${ }^{2, *}$ \\ ${ }^{1}$ Department of Microbiology, School of Medicine and ${ }^{2}$ Laboratory of Biomechanics and Biomedical Engineering, \\ Department of Mechanical Engineering and Aeronautics, University of Patras, Rion, Patras 26504, Greece
}

${ }^{\#}$ Both authors have contributed equally to this study

\begin{abstract}
The assessment of biomaterial susceptibility to infection relies mainly on the analysis of macroscopic bacterial responses to material interactions, usually under static conditions. However, new technologies permit a more profound understanding of the molecular basis of bacteriabiomaterial interactions. In this study, we combine both conventional phenotypic analysis - using confocal microscopy - and genotypic analysis - using the relative reverse transcription polymerase chain reaction (RT-PCR) - to examine the interaction of bacteria with $\mathrm{OH}-$ and $\mathrm{CH}_{3}$ terminated glass surfaces, under dynamic flow conditions. Bacterial adhesion, as well as slime production and biofilm formation, was much higher on the $\mathrm{CH}_{3}$-terminated than on the OH-terminated glass - for four Staphylococcus epidermidis strains. This was in agreement with the icaA and $i c a D$ gene expression results that showed increased expression for the bacteria adhering to the $\mathrm{CH}_{3}$-terminated substrate, especially under the higher shear rate. Therefore, the combined effect of the surface chemistry and shear significantly influence the adhesion and phenotype of interacting bacterial cells, while there are putative links between phenotypic responses to bacteria-material interactions and gene-expression profile alterations. This indicates that analysis of gene expression not only can greatly refine our knowledge of bacteria-material interactions, but also yield novel biomarkers for potential use in biocompatibility assessment.
\end{abstract}

Keywords: Bacterial adhesion; biomaterials; gene expression; surface chemistry; self-assembly; surface analysis; shear.

*Address for correspondence:
Yannis F. Missirlis
Laboratory of Biomechanics and Biomedical Engineering,
Department of Mechanical Engineering and Aeronautics
University of Patras,
Rion, Patras 26504, Greece

E-mail: yfmissirlis@gmail.com

\section{Introduction}

Infection remains one of the major impediments to the long-term use of many implanted and intravascular devices and Staphylococcus epidermidis, along with S. aureus, is the bacterium mainly associated with nosocomial device-related infections (Costerton et al., 1999; Rohde et al., 2010). Studies have shown that the pathogenesis of $S$. epidermidis is strongly correlated to the ability of microorganisms to form biofilm (Costerton et al., 1999; Mack at al., 2007; Rohde et al., 2010; Otto, 2012). The primary attachment step involves interactions of the bacterial surface with the physicochemical properties of the biomaterial followed by the involvement of adhesins, under flow conditions (Heilmann et al., 1996; Razatos et al., 1998; Katsikogianni and Missirlis, 2010; Rohde et al., 2010). The accumulative phase of biofilm formation mainly depends on polysaccharide intercellular adhesin (PIA) or poly- $N$-acetylglucosamine polysaccharide (PNAG) synthesis that is encoded by the icaADBC operon (Heilmann et al., 1996; Rohde et al., 2010; Otto M, 2012).

However, there is still a limited understanding of the key material surface control parameters that lead to prescribed bacterial-material responses. One of the reasons is that for many of the materials used the surface chemistry is quite complex. Many commercially available materials may contain impurities and surface-active additives, such as antioxidants or processing aids, which further complicate interpretation of bacteria-material interactions and result in uncertainties concerning the types of functional groups present at the surface (Tyler et al., 1992). Surface modification by means of plasmaprocessing techniques, for example, usually introduce numerous functional groups and chemical crosslinks (Wang et al., 1995; Balazs et al., 2003; Katsikogianni et al., 2006) while chemical treatments often cause severe degradation of the surface - leading to increased roughness as well as to surface heterogeneity (Katsikogianni et al., 2006). Time-dependent conformational rearrangements may also be observed (Silver et al., 1999; Katsikogianni et al., 2008), while antibiotic loading, and release rates are difficult to control over long periods (Popat et al., 2007) and the risks for the spread of antibiotic resistance following the biomaterial prophylactic and therapeutic clinical use should also be considered (Campoccia et al., 2010).

For these reasons, a rigorous study of the effects of surface chemistry on bacterial adhesion and gene expression requires a model system that allows precise control of the type and the configuration of functional 
groups at the substratum surface. In this direction, much interest has arisen in self-assembled monolayers (SAMs), with the goal of developing molecular-level control over surface properties (Wasserman et al., 1989; Mrksich, 1997) and providing the capability to circumvent many of the aforementioned experimental uncertainties (Mrksich, 1997).

However, the preparation of SAMs by the absorption of organosilanes onto hydroxylated substrates in solution can be rather tricky as the deposition of aggregated organosilane molecules frequently degrades the quality of the SAMs, increasing roughness and surface heterogeneity (Sugimura et al., 2002; Faucheux et al., 2004).

Since it has been proven that bacterial adhesion is influenced not only by surface chemistry but roughness and configuration as well (Scheuerman et al., 1998; Truong et al., 2010), we prepared $\mathrm{CH}_{3}$-terminated SAMs at the vapour/solid interface (Sugimura et al., 2002) in order to have smooth substrates. We could then examine the effect of the material surface chemistry, energy and charge on bacterial adhesion and icaA and icaD expression, in a direct manner.

Assessment of icaADBC operon's gene expression has become crucial to understanding the pathogenesis of $S$. epidermidis infections (Gerke et al., 1998; Vandecasteele et al., 2003; Vuong et al., 2004; Cerca et al., 2005; Kajiyama et al., 2009). Reverse transcription (RT), followed by polymerase chain reaction (RT-PCR), represents a powerful tool for gene expression studies through the detection and quantification of mRNA. Quantification is realised, by the relative RT-PCR, by the determination of the expression level of the target gene versus a housekeeping gene (Pfaffl, 2004).

There is evidence of up- and down-regulation of a number of genes, which occurs in the attaching bacteria upon initial interaction with the substratum. Davies and Geesey (1995) showed that during Pseudomonas aeruginosa biofilm formation in continuous culture, bacteria already attached to a glass substrate - for at least $15 \mathrm{~min}$ and for up to 25 days - exhibited up-expression of the alginate biosynthesis gene, $\operatorname{alg} C$. Moreover, bacterial cells not exhibiting $\operatorname{alg} C$ up-regulation, although managed to attach, were shown to be less capable of remaining to the glass surface under flow, than bacteria in which $\operatorname{alg} C$ up-expression was observed. In another study, PrigentCombaret et al. (1999) reported that major changes in the pattern of gene expression occur during biofilm development, as the transcription of $38 \%$ of the genes was affected within the biofilm. For example, the colonic acid exopolysaccharide ( $w c a$ locus) was more expressed in adhered bacteria than in planktonic, whereas the flagellin $(f i C)$ was reduced in biofilms. Furthermore, Becker et al. (2001) identified five genes that were differentially expressed in biofilm and planktonic populations of $S$. aureus. None of these studies though employed RT-PCR for the detection of gene expression. In a recent study, the icaA gene expression among clinical and reference $S$. epidermidis strains was examined under static conditions, and the results showed that the level of biomaterial-induced icaA expression could not be correlated with the amount of biofilm formed, or the material physicochemical properties, but with the ability of bacteria in surviving antibiotic attack (Nuryastuti et al., 2011).

According to our knowledge, there is no publication so far relating in a direct way the effect of the material surface chemistry on icaA and icaD expression in dynamic experiments, under different flow conditions.

However, shear generated by local haemodynamics may modulate the bacterial adhesion process (Goldsmith and Turitto, 1986). Although there is a lot of experimental work on the critical shear rate to prevent adhesion or to simulate detachment (Meiders et al., 1995; Boks et al., 2008a; Boks et al., 2008b), little previous work exists on bacterial adhesion to model SAMs under a wide range of shear rates (Wiencek and Fletcher, 1995; Nejadnik et al., 2008). Moreover, although it has been shown that shear stress strengthens bacterial attachment to red blood cells (Thomas et al., 2002), the effect of shear on bacterial gene expression has not yet been examined. For this reason, in this work bacterial adhesion to $\mathrm{OH}$ - and $\mathrm{CH}_{3}$ - terminated glass and ica gene expression were examined under two shear rates 50 and $2000 \mathrm{~s}^{-1}$, that correspond to the physiological shear rates for stable laminar flow in blood vessels (Goldsmith and Turitto, 1986).

In this direction, the present study attempts to answer in a fundamental way, by using the simplest possible chemistries, the following questions: Does the surface chemistry influence $S$. epidermidis adhesion and ica gene expression? How does adhesion and gene expression depend on shear rate and on the relative contribution of physicochemical and hydrodynamic interactions? These questions were addressed by quantitative measurements of bacterial adhesion, biofilm formation, PIA production and relative expression of $i c a A$ and $i c a D$ genes towards a $207 \mathrm{bp}$ part of $23 \mathrm{~S}$ rDNA on surfaces in laminar flow as a function of surface chemistry and fluid shear rate. In this contribution, the preparation and characterisation of hydroxylated glass substrates and $\mathrm{CH}_{3}$-terminated SAMs are briefly described.

\section{Materials and Methods}

\section{Bacterial strains and culture conditions}

Four S. epidermidis strains were used. Two reference strains; ATCC35984 (RP62A), a well characterised slime producing/ica-positive strain, and ATCC12228, a slimenegative/ica-negative one, that were used as positive and negative controls respectively, and two clinical strains; the slime-positive/ica-positive GRE4388 and the slimenegative/ica-positive GRE2264, isolated from catheter infections of hospitalised patients at the Microbiology Laboratory of the University Hospital of Patras. The strains were characterised by biochemical tests (phenotype: 6706113 according to the analytical profile of API Staph System, bioMerieux, Lyon, France), and molecularly by restriction fragment length polymorphism of an amplified 370 bp part of the tuf gene (encoding elongation factor EF-Tu). The obtained restriction DNA fragments were 243 bp and 127 bp by BstZ171 and 246 bp, 86 bp and 38 bp by BseNI (Kontos et al., 2003). Slime production was tested by inoculating 4-5 colonies of the reference 
(used as controls) and clinical strains in plastic tubes with $10 \mathrm{~mL}$ of Trypticase soy broth (bioMerieux) incubated $\mathrm{O} / \mathrm{N}$ at $37^{\circ} \mathrm{C}$, inclined at $45^{\circ}$; the broth was gently discarded and slime was stained with $0.1 \%$ safranin solution (Ishak et al., 1985). The presence of ica operon was detected by PCR (Arciola et al., 2002).

Before each experiment, bacteria were cultured in Brain-Heart Infusion Broth (BHIB, Difco Laboratories, Detroit, MI, USA) and harvested while being in the midexponential phase (Vandecasteele et al., 2003). Afterwards, they were resuspended in $0.9 \% \mathrm{NaCl}$ at a concentration of $3 \times 10^{9}$ colony forming units (cfu) $/ \mathrm{mL}$ (according to the McFarland standard, bioMerieux).

\section{Preparation and characterisation of self-assembled monolayers and bacterial cells}

The Self-Assembled Monolayers (SAMs) were prepared as described by Katsikogianni and Missirlis (2010). Briefly, the hydroxyl $(\mathrm{OH})$ terminated glass substrates were prepared by hydrolysing the glass slides (Knittel Gläser, Braunschweig, Germany) in $5 \mathrm{M} \mathrm{NaOH}$ (Carlo Erba, Renningen, Germany) followed by oxidation in piranha solution that converted all groups to silanol ( $\mathrm{Si}-\mathrm{OH})$. The $\mathrm{CH}_{3}$-terminated monolayers were prepared by using octadecyltriethoxysilane (ODS, Gelest Inc., Morrisville, PA, USA) and following the vapour phase method at elevated temperature (Sugimura et al., 2002).

The material surface properties were characterised as described by Katsikogianni and Missirlis (2010). In brief, the topography of the $\mathrm{OH}$ - and $\mathrm{CH}_{3}$ - terminated glass surfaces was examined by means of a Multimode AFM (Nanoscope III, Veeco, Plainview, NY, USA). The surface energy of the substrates and its components were evaluated using the "Lifshitz-van der Waals acid-base" ("LW-AB") approach, after measuring the contact angles of three probe liquids; ultrapure water, methylene iodide and glycerol, on the various substrates and bacterial strains. A Laser Zeta Meter (Malvern Instruments Ltd., Worcestershire, $\mathrm{UK}$ ) was used to determine the zeta potential of $\mathrm{OH}-$ and $\mathrm{CH}_{3}$ - terminated glass beads and the various bacterial strains after their suspension in $0.9 \% \mathrm{NaCl}$. The total energy of bacterial adhesion was calculated according to the Extended (X) DLVO theory and expressed as the sum of the LW, AB and electrostatic (EL) interaction energies (Van Oss et al., 1986)

\section{Dynamic bacterial adhesion assays}

To evaluate the bacterial adhesion under flow conditions and investigate the combined effect of flow and surface chemistry on ica gene expression, the parallel plate flow chamber (PPFC) described by Stavridi et al. (2003), was used. The pump was programmed to travel the pistons back and forth every $60 \mathrm{~s}$. The shear rate (S) was calculated by the following formula:

$$
S=\frac{6 Q}{W h^{2}}
$$

where $Q$ is the flow rate, $W$ (width of the chamber) $=0.015 \mathrm{~m}$ and $h$ (height of the chamber) $=0.35 \times 10^{-3} \mathrm{~m}$.

All experiments were carried out at $37^{\circ} \mathrm{C}$ by placing the experimental setup inside a thermostatically controlled box (INFORS HT, Bottmingen, Switzerland). A volume of $10 \mathrm{~mL}$ of each bacterial suspension at a concentration of $3 \times 10^{9} \mathrm{cfu} / \mathrm{mL}$ in $0.9 \% \mathrm{NaCl}$ was introduced to the system. Two shear rates were used: 50 and $2000 \mathrm{~s}^{-1}$. Each experiment was performed three times for each bacterial strain. Two incubation times of the bacteria with the substrates were examined; two and four hours. Every experiment was repeated with fresh bacterial suspensions that were immediately inserted into the flow chambers, after bacterial resuspension in $0.9 \% \mathrm{NaCl}$.

\section{Examination and quantification of bacterial adhesion and biofilm formation}

Colony forming units counting method

After the adhesion experiments, adherent bacteria were detached by immersing each sample in $1 \mathrm{~mL}$ trypsin (Sigma-Aldrich) at $37^{\circ} \mathrm{C}$ for $5 \mathrm{~min}$ and using a cell scraper (Sigma-Aldrich). Trypsin was inactivated by adding $2.5 \mathrm{~mL}$ of foetal bovine serum (FBS, Sigma-Aldrich) in each sample. Then 10-fold serial dilutions of the detached adherent bacteria were inoculated onto Trypticase soy agar (TSA, Difco Laboratories, Detroit, MI, USA) plates, and the numbers of adherent bacterial colonies were counted after $18 \mathrm{~h}$ of incubation at $37^{\circ} \mathrm{C}$ (An and Friedman, 1997).

\section{Scanning electron microscopy}

Prior to examination with scanning electron microscope (SEM), each sample was fixed for $20 \mathrm{~min}$ with $2.5 \%$ glutaraldehyde (Sigma-Aldrich) in $0.9 \% \mathrm{NaCl}$ (An and Friedman, 1997). Afterwards, the samples were dehydrated by several passages in ethanol-water solutions for $20 \mathrm{~min}$ each, using increasing concentrations of ethanol up to $100 \%$, sputter coated with gold and subsequently investigated with SEM (JEOL-JSM 6300, Hertfordshire, UK). Fixation and dehydration took place inside the flow chambers, and care was taken to avoid the formation and the passage of an air-liquid interface over the bacteriacovered surface. Such an interface would probably cause high shear and result in bacterial detachment and redistribution, especially in the case of hydrophobic surfaces (Boks et al., 2008b).

\section{Scanning confocal laser microscopy}

In order to examine bacterial adhesion and PIA production by adherent bacteria, a fluorescently labelled lectin with Texas red; Wheat Germ Agglutinin (WGA) (Molecular Probes, Invitrogen, Paisley, Scotland, UK) was used in combination with the fluorescent DNA-binding stain SYTO 9 (Molecular Probes, Invitrogen). WGA specifically binds to $\mathrm{N}$-acetyl-glycosaminoglycan that is the main component of PIA, while SYTO 9 was used to visualise the distribution of adherent bacteria (Strathmann et al., 2002).

After fixation with $3 \%$ formaldehyde and staining, the samples were examined by scanning confocal laser microscopy (SCLM) (TE 2000, Nikon, Lijnden, Netherlands) (Strathmann et al., 2002).

Images were processed using the Image Pro Plus analysis software (Media Cybernetics), in order to quantify the percentage of surface area covered by biofilm and the percentage of the bacterial cells covered by PIA. 


\section{ica gene expression study}

After the adhesion experiments, the adherent bacteria were detached by immersing each sample in $1 \mathrm{~mL}$ trypsin (Sigma-Aldrich) at $37^{\circ} \mathrm{C}$ for $5 \mathrm{~min}$ and using a cell scraper (Sigma-Aldrich). Trypsin was inactivated with $2.5 \mathrm{~mL}$ foetal bovine serum (FBS, Sigma-Aldrich) and bacteria were collected by centrifugation. The bacterial pellets, kept at $-20^{\circ} \mathrm{C}$, were used for RNA isolation, within a week after collection.

Total RNA extraction from each sample was performed by the Trizol method (Invitrogen, Carlsbad, USA). The samples were examined in sets of four so that their processing was well controlled and consistent. Briefly, cells from each sample were washed with $1.5 \mathrm{~mL}$ of DEPC-treated water $(0.1 \%)$ (Invitrogen). The pellet was resuspended in $100 \mu \mathrm{L} \mathrm{TE}(\mathrm{pH}=8)$ containing $2 \mathrm{mg}$ lysozyme (Sigma-Aldrich) and incubated at $37^{\circ} \mathrm{C}$, for $10 \mathrm{~min}$, followed by the addition of $1 \mathrm{~mL}$ Trizol (Invitrogen) and further incubation at $30{ }^{\circ} \mathrm{C}$ for $30 \mathrm{~min}$. Chloroform $(200 \mu \mathrm{L})$ was added and the samples were incubated at $-20^{\circ} \mathrm{C}$ for $30 \mathrm{~min}$, using vortexing in between. After centrifugation at $12,000 \mathrm{~g}$, at $2-8{ }^{\circ} \mathrm{C}$, for $15 \mathrm{~min}$, the supernatant was transferred into an Eppendorf tube and RNA was precipitated with $500 \mu \mathrm{L}$ isopropanol (Chini et al., 2007). RNA was finally dissolved in $50 \mu \mathrm{L}$ DEPC-water and treated with 3 IU RNase-free DNase (Promega, Madison, WI, USA) at $37^{\circ} \mathrm{C}$ for $1 \mathrm{~h}$. RNA was quantified measuring the absorbance at $260 \mathrm{~nm}$ (Sambrook et al., 1998), while nucleic acid purity was assessed by $A 260 \mathrm{~nm} / \mathrm{A} 280 \mathrm{~nm}$ ratio (acceptable if $>1.6$ ). Genomic DNA contamination was tested by PCR with specific primers, using the appropriate reaction mix composition and thermal conditions for icaA and icaD genes (Arciola et al., 2002) and a 207 bp part of the region $\mathrm{V}$ in the 23S rDNA gene designed by us $(23 S r D N A$-forward: 5'-CTTATCTCCCCCAAGAGT-3' and 23SrDNA-reverse: 5'- TCTCGTACTAAGGACAGCTC-3'). Complementary DNA (cDNA) synthesis was carried out using $0.5 \mathrm{ng}$ total RNA, 50 ng random hexamers primers and the SuperScript First-Strand Synthesis System for RT-PCR (Invitrogen).

Real Time PCR for icaA, icaD genes, and a $207 \mathrm{bp}$ part of the region $\mathrm{V}$ in the $23 \mathrm{~S}$ rDNA gene were carried out with the RotorGene device (RG-3000, Corbett Research, Sydney, Australia). The same primers used for the conventional PCRs were applied, while icaA and $i c a D$ genes were selected to be tested as markers of ica operon activity, because they encode the first two components of biofilm formation The icaA gene product is a transmembrane protein with homology to $\mathrm{N}$-acetyl glucosaminyltransferases, requiring the $i c a \mathrm{D}$ gene product for optimal activity (Gerke C et al., 1998; Otto M, 2012). All reactions were carried out using $5 \mu \mathrm{L}$ of cDNA (diluted 1:10), 2x SYBR ${ }^{\circledR}$ Green I master mix (Invitrogen) and specific primers (Chini et al., 2007). For icaA and icaD genes the cycling conditions were: $50^{\circ} \mathrm{C}$ for $2 \mathrm{~min} ; 95^{\circ} \mathrm{C}$ for $5 \mathrm{~min}$; 45 cycles of $95^{\circ} \mathrm{C}$ for $20 \mathrm{~s}, 58{ }^{\circ} \mathrm{C}$ for $20 \mathrm{~s}$ and $72{ }^{\circ} \mathrm{C}$ for $20 \mathrm{~s}$; a final elongation step at $72{ }^{\circ} \mathrm{C}$ for $5 \mathrm{~min}$. For $23 \mathrm{~S}$ rDNA gene, thermal conditions were $50{ }^{\circ} \mathrm{C}$ for $2 \mathrm{~min} ; 95^{\circ} \mathrm{C}$ for $5 \mathrm{~min} ; 45$ cycles of $95^{\circ} \mathrm{C}$ for $20 \mathrm{~s}, 53{ }^{\circ} \mathrm{C}$ for $20 \mathrm{~s}$ and $68{ }^{\circ} \mathrm{C}$ for $20 \mathrm{~s}$; a final elongation step at $68{ }^{\circ} \mathrm{C}$ for $5 \mathrm{~min}$. Each run included the ica- negative and a non-template control as negative controls. Specificity of the PCR products was confirmed by analysis of the dissociation curve. Results were evaluated using the RotorGene analysis software 6.0. The amplicons' expected size and the absence of non-specific products were confirmed by conventional PCR with the same primers. Efficiency of reactions was calculated from the slope according to the equation $\mathrm{E}=10^{-1 / \text { slope }}$ (Pfaffl, 2004).

Absolute Real-Time PCR was performed as described by Chini et al. (2007). icaA, icaD, and 23S rDNA genes of the reference ATCC35984 strain were amplified by conventional PCRs and prepared as standards. The amplicons were purified (Wizard PCR Preps DNA Purification System, Promega, Madison, WI, USA) and their concentrations were calculated (Chini et al., 2007). In order to quantify the expression level of each gene the cDNA's of each sample were amplified by RT-PCR, followed by importation of the standard curve of each gene and the results were expressed as copies/ $\mu \mathrm{L}$ (Chini et al., 2007).

Relative RT-PCR constituted the rate of the expression levels of tested genes comparing the absolute values of each gene towards those of the reference (23S rDNA) (Fluckiger et al., 2005). PCR efficiencies were first established for each pair of primers.

\section{Statistical analysis}

The effects of the surface chemistry and flow conditions on bacterial adhesion, biofilm formation, PIA production and $i c a A$ and $i c a D$ gene expression were statistically analysed using the SPSS package for windows. One way analysis of variance (ANOVA) was performed using the Scheffe significant difference test. Moreover, regression analysis and correlation coefficients $\left(R^{2}\right)$ were obtained using SPSS. Correlations were taken as significant for $p<0.01$.

\section{Results}

\section{Physicochemical properties of the substratum and the bacterial surfaces-interaction energies}

The AFM analysis of the substrates revealed that the silanisation of the glass with ODS at the vapour/solid interface did not significantly influence the surface morphology and the $\mathrm{Ra}$ values ( $\mathrm{Ra}$ of $\mathrm{CH}_{3}$-terminated glass: $1.2 \pm 0.2 \mathrm{~nm}$ and of the $\mathrm{OH}$-terminated ones: $0.9 \pm 0.2 \mathrm{~nm}$ ). As detailed in (Katsikogianni and Missirlis, 2010), the $\mathrm{CH}_{3}$-terminated surface presents significantly higher contact angles for all the three tested liquids liquids; water, methylene iodide and glycerol in comparison to the $\mathrm{OH}$-terminated glass. Moreover, according to the Lifshitzvan der Waals $(\mathrm{LW})\left(\gamma_{S}^{L W}\right)$ - acid-base $(\mathrm{AB})\left(\gamma_{S}^{A B}\right)$ approach (Van Oss, 1986; Katsikogianni and Missirlis, 2010) and the results presented in Table 1, the ATCC35984 and GRE2264 bacterial strains and the $\mathrm{OH}$-terminated glass appear to be polar $\left(\gamma_{s}^{A B}>\gamma_{s}^{L W}\right)$, whereas the ATCC12228 and GRE4388 bacterial strains and the $\mathrm{CH}_{3}$-terminated SAM are rather hydrophobic $\left(\gamma_{s}^{L W}>>\gamma_{s}^{A B}\right)$. Accordingly, the electron donor parameter $\left(\gamma_{s}^{-}\right)$of the ATCC35984 and GRE2264 bacterial strains and the $\mathrm{OH}$-terminated glass is much higher than the electron acceptor $\left(\gamma_{s}^{+}\right)$. In contrast, the $\gamma_{s}^{A B}, \gamma_{s}^{-}, \gamma_{s}^{+}$of 
Table 1. Material and biomaterial total surface free energy $\left(\gamma_{S}^{L W-A B}\right)$, its apolar $\left(\gamma_{s}^{L W}\right)$ and polar $\left(\gamma_{S}^{A B}\right)$ components, the electron donor $\left(\gamma_{s}^{-}\right)$and the electron acceptor character $\left(\gamma_{S}^{+}\right)$, as these are calculated according to the "Lifshitz-van der Waals acid-base" approach. Zeta potential $(\zeta)$ in $\mathrm{mV}$, of the two substrates and the various bacterial strains (Three samples were independently prepared and three measurements were taken on each one). The surface energy parameters for Glass-OH, Glass-CH $\mathrm{CH}_{3}$, ATCC35984 and ATCC12228 have been also presented in Katsikogianni and Missirlis, 2010.

\begin{tabular}{lcccccc}
\hline \multicolumn{1}{c}{$\begin{array}{c}\gamma_{S}^{L W} \\
\text { Sample }\end{array}$} & $\begin{array}{c}\gamma_{S}^{+} \\
\left(\mathrm{mJ} / \mathrm{m}^{2}\right)\end{array}$ & $\begin{array}{c}\gamma_{S}^{-} \\
\left(\mathrm{mJ} / \mathrm{m}^{2}\right)\end{array}$ & $\begin{array}{c}\gamma_{S}^{A B} \\
\left(\mathrm{~mJ} / \mathrm{m}^{2}\right)\end{array}$ & $\begin{array}{c}\gamma_{S}^{L W-A B} \\
\left(\mathrm{~mJ} / \mathrm{m}^{2}\right)\end{array}$ & $\begin{array}{c}* \zeta(\mathrm{mV}) \\
\left(\mathrm{mJ} / \mathrm{m}^{2}\right)\end{array}$ & $0.9 \% \mathrm{NaCl}$ \\
\hline Glass-OH & 24.7 & 6.4 & 51.8 & 36.3 & 60.9 & $-16.2 \pm 4.9$ \\
Glass-CH $_{3}$ & 31.7 & 1.2 & 0.03 & 1.19 & 32.9 & $-5.3 \pm 6.1$ \\
ATCC35984 & 26.0 & 5.7 & 45.3 & 32.2 & 58.2 & $-13.8 \pm 4.1$ \\
ATCC12228 & 17.9 & 0.01 & 0.5 & 0.08 & 17.9 & $-12.2 \pm 3.1$ \\
${ }^{*}$ GRE4388 & 21.4 & 0.12 & 1.9 & 0.96 & 22.4 & $-10.2 \pm 4.4$ \\
${ }^{*}$ GRE2264 & 25.2 & 5.3 & 49.8 & 32.5 & 57.7 & $-14.1 \pm 2.8$ \\
\hline
\end{tabular}

*These data are new, while the rest are from the Reference Katsikogianni and Missirlis, 2010.

the ATCC12228 and GRE4388 bacterial strains and the $\mathrm{CH}_{3}$-terminated SAMs appear low, reflecting their apolar character. The LW component of the various bacteria and material surface free energy does not vary as much as the AB component. The Zeta potential measurements $(\zeta)$ showed the $\mathrm{OH}$-terminated glass is negatively charged whereas the $\mathrm{CH}_{3}$ SAMs present low charge (Table 1). All bacteria are negatively charged.

Table 2 presents the total interaction energies $\left(U_{d=1 n m}^{x D L}\right)$, evaluated using the XDLVO theory, among the four $\mathrm{S}$. epidermidis strains and the $\mathrm{OH}$ and $\mathrm{CH}_{3}$ - terminated substrates for distance $\mathrm{d}=1 \mathrm{~nm}$. According to the results, all bacterial strains should be attracted to the $\mathrm{CH}_{3}$ SAM due to the attractive $\mathrm{AB}$ interactions that are the predominant ones at close distance. Moreover, although the EL and LW interactions are not significantly different between the four bacterial strains, the $\mathrm{AB}$ interactions are, due to their significantly different surface free energy components. Therefore, according to the XDLVO theory, ATCC12228 and GRE4388 should be more adherent than ATCC35984 and GRE2264, due to the differences in their polarity and consequently due to the differences in the $\mathrm{AB}$ interactions. This was in agreement with the experimental results that follow.

\section{Bacterial adhesion and biofilm formation Colony forming units counting method}

Fig. 1 shows the combined effect of surface chemistry and shear rate on bacterial adhesion (number of adherent bacteria $/ \mathrm{cm}^{2}$ ), as this was quantified by the Colony Forming Unit (CFU) method, for ATCC35984 (Fig. 1a), ATCC12228 (Fig. 1b), GRE4388 (Fig. 1c) and GRE2264 (Fig. 1d). These results showed that all four bacterial strains presented similar adhesion trends; they adhered significantly more to the $\mathrm{CH}_{3}$-terminated glass in comparison with the $\mathrm{OH}$-terminated one $(p<0.01)$. The adhesion events were increased after $4 \mathrm{~h}$ of incubation into the PPFC. A decrease in the number of adherent bacteria, for all materials and bacterial strains, was observed when the shear rate increased from $50 \mathrm{~s}^{-1}$ to $2,000 \mathrm{~s}^{-1}$. This decrease was significantly different $(p<0.01)$, for all possible combinations. The lowest number of attached bacteria was calculated under the higher shear rate onto the $\mathrm{OH}$-terminated surface, for all bacterial strains. Under the aforementioned conditions, the clinical slime-positive strain (GRE4388) showed the highest number of attached bacteria $\left(1.31 \times 10^{9}\right.$ bacteria $\left./ \mathrm{cm}^{2}\right)$, even in comparison to the reference slime-positive strain ATCC35984 (7.42 x $10^{8}$ bacteria $/ \mathrm{cm}^{2}$ ). The reference slime-negative strain ATCC12228 presented similar values of attached bacteria on the $\mathrm{OH}$-terminated substrates, under both shear rates, as the reference ATCC35984. Moreover, it presented higher values of attached bacteria on the $\mathrm{CH}_{3}$-terminated substrate, under both shear rates, in comparison with ATCC35984. The clinical slime-negative strain (GRE2264) presented the lowest number of adherent bacteria; in comparison to all other bacterial strains for all the possible combinations $(p<0.01)$.

\section{Scanning electron microscopy}

The SEM images revealed that, apart from the fact that the $\mathrm{CH}_{3}$-terminated substrate yielded the highest number of adherent bacteria for all four bacterial strains, ATCC35984 (Figs. 2a and 2d) and GRE4388 (Figs. 2e and 2f), that are slime-positive, produced slime only when they were attached to the $\mathrm{CH}_{3}$-terminated substrate (Figs. 2a, 2b, 2e and $2 \mathrm{f}$ ), under both shear rates and 2 or $4 \mathrm{~h}$ post-adhesion, whereas isolated bacteria or small aggregates were observed onto the $\mathrm{OH}$-terminated glass (Figs. 2c and 2d).

In the case of ATCC 35984, under the higher shear rate conditions and $4 \mathrm{~h}$ of adhesion (Fig. 2b), the patterns of adhesion had essentially the same form, as in the case of the lower shear rate. However, the adherent to the $\mathrm{CH}_{3}$ substrate bacterial aggregates were smaller and the biofilm thinner and denser, as this was verified and quantified by the confocal microscopy measurements (Table 3 ).

In the case of GRE4388, $4 \mathrm{~h}$ after adhesion under high shear rate, there was an increase in both the number of adherent bacteria and the quantity of slime, without influencing the biofilm thickness (Fig. 2f), as this was 

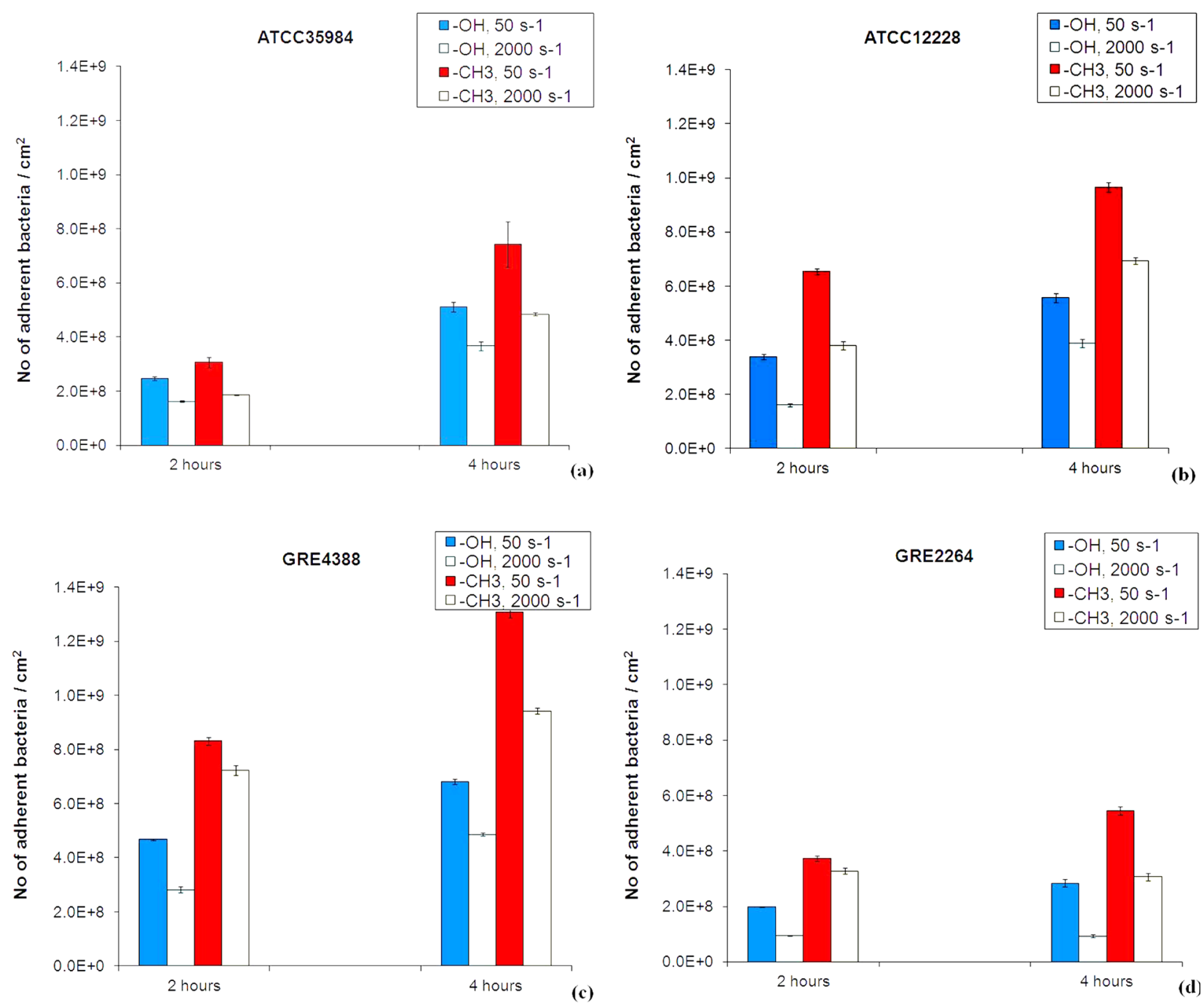

Fig. 1. Mean values and standard deviation $(n=3)$ of the number of adherent ATCC35984 (slime-positive/ica-positive) (a), ATCC12228 (slime-negative/ica-negative) (b), GRE4388 (slime-positive/ica-positive) (c) and GRE2264 (slimenegative/ica-positive) (d) bacteria/ $\mathrm{cm}^{2}(N)$ onto the $\mathrm{OH}$ - and $\mathrm{CH}_{3}$ - terminated substrates under shear rate of $50 \mathrm{~s}^{-1}$ and $2,000 \mathrm{~s}^{-1} \cdot p<0.001$ for all the possible combinations.

Table 2. Total interaction energies $\left(U_{d=1 n m}^{X D L V}\right)$, evaluated according to the XDLVO theory, between the various bacterial strains and the $\mathrm{OH}$ and $\mathrm{CH}_{3}$ - terminated glass, for distance $\mathrm{d}=1 \mathrm{~nm}$.

\begin{tabular}{l|cccc}
\hline & $U_{d=1 m}^{X D L V O}$ & $U_{d=1 m}^{X D L V O}$ & $U_{d=1 m}^{X D L V O}$ & $U_{d=1 m}^{X D L V O}$ \\
& $(J)$ & $(J)$ & $(J)$ & $(J)$ \\
Sample & $A T C C 35984$ & $A T C C 12228$ & $G R E 4388$ & $G R E 2264$ \\
\hline Glass-OH & $2.75 \mathrm{E}-17$ & $9.89 \mathrm{E}-19$ & $1.12 \mathrm{E}-20$ & $3.06 \mathrm{E}-17$ \\
Glass- $\boldsymbol{C H}_{3}$ & $-1.30 \mathrm{E}-17$ & $-1.05 \mathrm{E}-16$ & $-0.87 \mathrm{E}-16$ & $-1.17 \mathrm{E}-17$ \\
\hline
\end{tabular}



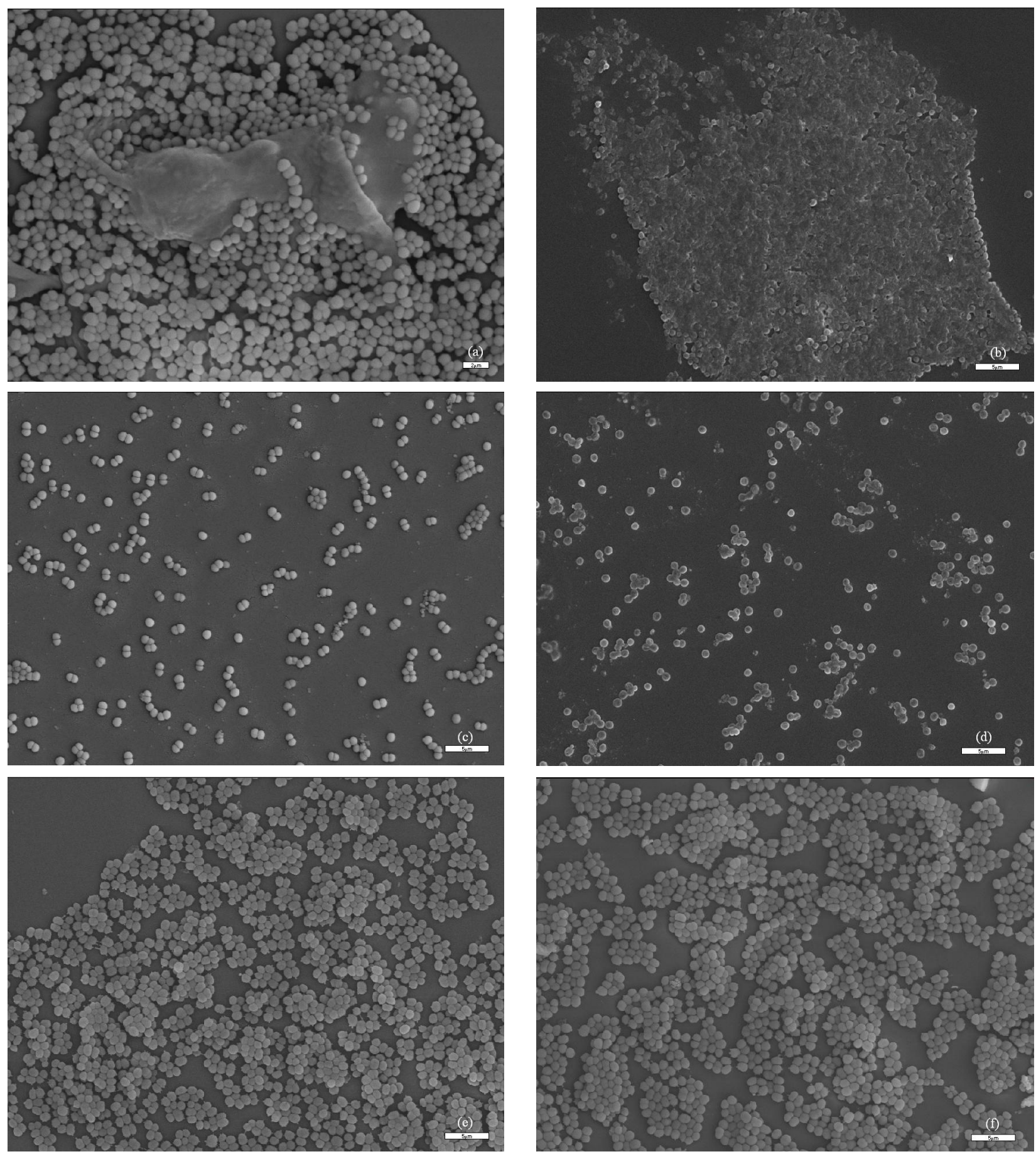

Fig. 2. SEM images of ATCC35984 interacting with the $\mathrm{CH}_{3}$-terminated substrate under 2,000 s-1, two (a) and four (b) hours after adhesion, of ATCC35984 interacting with the OH-terminated substrate under $50 \mathrm{~s}^{-1}(\mathbf{c})$ and 2,000 s-1 (d), two hours after adhesion and of GRE4388 interacting with the $\mathrm{CH}_{3}$-terminated substrate under 2,000 s-1, two (e) and four (f) hours after adhesion. Scale bars represent $2 \mu \mathrm{m}$ for image (a) and $5 \mu \mathrm{m}$ for images (b-f). 
Table 3: Mean values and standard deviation $(n=3)$ of $\%$ surface coverage of the surface by biofilm, biofilm thickness and \% coverage of biofilm by PIA, as these were quantified using SCLM and image analysis.

\begin{tabular}{|c|c|c|c|}
\hline Samples & $\begin{array}{c}\text { \% Biofilm } \\
\text { Coverage of the } \\
\text { Surface }\end{array}$ & $\begin{array}{c}\text { Biofilm } \\
\text { Thickness ( } \mu \mathrm{m})\end{array}$ & $\begin{array}{l}\text { \% Coverage of } \\
\text { Biofilm by PIA }\end{array}$ \\
\hline ATCC35984, $50 \mathrm{~s}^{-1}, 2 \mathrm{~h}, \mathrm{OH}$ & $10.3 \pm 2.1$ & $1.3 \pm 0.5$ & $39.7 \pm 4.3$ \\
\hline ATCC $35984,2000 \mathrm{~s}^{-1}, 2 \mathrm{~h}, \mathrm{OH}$ & $8.5 \pm 1.9$ & $0.9 \pm 0.8$ & $51.7 \pm 3.5$ \\
\hline ATCC35984, $50 \mathrm{~s}^{-1}, 4 \mathrm{~h}, \mathrm{OH}$ & $18.6 \pm 3.9$ & $1.7 \pm 0.4$ & $42.3 \pm 3.1$ \\
\hline ATCC35984, $2000 \mathrm{~s}^{-1}, 4 \mathrm{~h}, \mathrm{OH}$ & $7.9 \pm 2.7$ & $0.8 \pm 0.7$ & $23.5 \pm 4.2$ \\
\hline $\mathrm{ATCC} 35984,50 \mathrm{~s}^{-1}, 2 \mathrm{~h}, \mathrm{CH}_{3}$ & $71.1 \pm 3.3$ & $5.3 \pm 0.3$ & $80.7 \pm 2.5$ \\
\hline ATCC $35984,2000 \mathrm{~s}^{-1}, 2 \mathrm{~h}, \mathrm{CH}_{3}$ & $62.5 \pm 2.4$ & $3.9 \pm 0.2$ & $87.6 \pm 3.2$ \\
\hline ATCC35984, $50 \mathrm{~s}^{-1}, 4 \mathrm{~h}, \mathrm{CH}_{3}$ & $87.3 \pm 3.1$ & $6.1 \pm 0.4$ & $81.3 \pm 2.3$ \\
\hline ATCC $35984,2000 \mathrm{~s}^{-1}, 4 \mathrm{~h}, \mathrm{CH}_{3}$ & $57.5 \pm 2.9$ & $3.8 \pm 0.9$ & $72.5 \pm 2.5$ \\
\hline ATCC12228, $50 \mathrm{~s}^{-1}, 2 \mathrm{~h}, \mathrm{OH}$ & $13.7 \pm 2.4$ & $1.2 \pm 0.3$ & $2.7 \pm 1.3$ \\
\hline ATCC12228, $2000 \mathrm{~s}^{-1}, 2 \mathrm{~h}, \mathrm{OH}$ & $9.8 \pm 2.7$ & $0.7 \pm 0.4$ & $1.9 \pm 1.5$ \\
\hline ATCC12228, $50 \mathrm{~s}^{-1}, 4 \mathrm{~h}, \mathrm{OH}$ & $23.5 \pm 2.9$ & $1.9 \pm 0.5$ & $2.3 \pm 1.1$ \\
\hline ATCC12228, $2000 \mathrm{~s}^{-1}, 4 \mathrm{~h}, \mathrm{OH}$ & $11.9 \pm 2.4$ & $0.7 \pm 0.8$ & $1.5 \pm 1.2$ \\
\hline 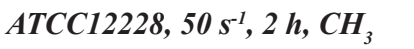 & $79.1 \pm 2.3$ & $5.5 \pm 0.2$ & $5.1 \pm 1.7$ \\
\hline ATCC12228, $2000 \mathrm{~s}^{-1}, 2 \mathrm{~h}, \mathrm{CH}_{3}$ & $71.5 \pm 2.3$ & $4.2 \pm 0.5$ & $4.6 \pm 1.2$ \\
\hline $\mathrm{ATCC} 12228,50 \mathrm{~s}^{-1}, 4 \mathrm{~h}, \mathrm{CH}_{3}$ & $92.3 \pm 5.1$ & $6.3 \pm 0.6$ & $3.3 \pm 1.9$ \\
\hline ATCC12228, $2000 \mathrm{~s}^{-1}, 4 \mathrm{~h}, \mathrm{CH}_{3}$ & $62.3 \pm 2.7$ & $3.9 \pm 1.2$ & $2.5 \pm 1.4$ \\
\hline GRE4388, $50 \mathrm{~s}^{-1}, 2 \mathrm{~h}, \mathrm{OH}$ & $18.2 \pm 3.1$ & $1.6 \pm 0.3$ & $33.5 \pm 2.2$ \\
\hline GRE4388, $2000 \mathrm{~s}^{-1}, 2 \mathrm{~h}, \mathrm{OH}$ & $8.5 \pm 1.9$ & $1.2 \pm 0.4$ & $45.3 \pm 2.7$ \\
\hline GRE4388, $50 \mathrm{~s}^{-1}, 4 \mathrm{~h}, \mathrm{OH}$ & $18.6 \pm 3.9$ & $1.9 \pm 0.7$ & $39.3 \pm 2.1$ \\
\hline GRE4388, $2000 \mathrm{~s}^{-1}, 4 \mathrm{~h}, \mathrm{OH}$ & $12.3 \pm 2.2$ & $1.1 \pm 0.3$ & $47.5 \pm 3.9$ \\
\hline GRE4388, $50 \mathrm{~s}^{-1}, 2 \mathrm{~h}, \mathrm{CH}_{3}$ & $84.3 \pm 4.3$ & $5.7 \pm 0.5$ & $77.2 \pm 1.6$ \\
\hline GRE4388, $2000 \mathrm{~s}^{-1}, 2 \mathrm{~h}, \mathrm{CH}_{3}$ & $78.7 \pm 2.2$ & $4.3 \pm 0.4$ & $84.5 \pm 2.2$ \\
\hline GRE4388, $50 \mathrm{~s}^{-1}, 4 \mathrm{~h}, \mathrm{CH}_{3}$ & $92.3 \pm 3.4$ & $6.4 \pm 0.6$ & $79.3 \pm 1.5$ \\
\hline GRE4388, $2000 \mathrm{~s}^{-1}, 4 \mathrm{~h}, \mathrm{CH}_{3}$ & $73.2 \pm 3.1$ & $4.3 \pm 0.7$ & $75.5 \pm 4.8$ \\
\hline GRE2264, $50 \mathrm{~s}^{-1}, 2 \mathrm{~h}, \mathrm{OH}$ & $8.3 \pm 1.7$ & $1.1 \pm 0.4$ & $1.9 \pm 1.4$ \\
\hline GRE2264, $2000 \mathrm{~s}^{-1}, 2 \mathrm{~h}, \mathrm{OH}$ & $6.5 \pm 2.3$ & $0.5 \pm 0.6$ & $1.5 \pm 0.9$ \\
\hline GRE2264, $50 \mathrm{~s}^{-1}, 4 \mathrm{~h}, \mathrm{OH}$ & $13.2 \pm 2.4$ & $1.1 \pm 0.3$ & $1.3 \pm 1.1$ \\
\hline GRE2264, $2000 \mathrm{~s}^{-1}, 4 \mathrm{~h}, \mathrm{OH}$ & $6.8 \pm 3.4$ & $0.7 \pm 0.8$ & $2.5 \pm 1.3$ \\
\hline GRE2264, $50 \mathrm{~s}^{-1}, 2 \mathrm{~h}, \mathrm{CH}_{3}$ & $62.3 \pm 2.7$ & $4.9 \pm 0.5$ & $3.1 \pm 1.4$ \\
\hline GRE2264, $2000 \mathrm{~s}^{-1}, 2 \mathrm{~h}, \mathrm{CH}_{3}$ & $57.3 \pm 2.4$ & $3.5 \pm 0.4$ & $3.6 \pm 1.2$ \\
\hline GRE2264, $50 \mathrm{~s}^{-1}, 4 \mathrm{~h}, \mathrm{CH}_{3}$ & $69.8 \pm 4.1$ & $5.1 \pm 0.7$ & $3.5 \pm 1.6$ \\
\hline GRE2264, $2000 \mathrm{~s}^{-1}, 4 \mathrm{~h}, \mathrm{CH}_{3}$ & $58.4 \pm 2.9$ & $2.9 \pm 1.5$ & $2.7 \pm 1.9$ \\
\hline
\end{tabular}

confirmed by the confocal microscopy. Slime produced by this bacterial strain appeared to be less in comparison to that produced by ATCC 35984, 2 and $4 \mathrm{~h}$ after adhesion.

Clusters of an average number of 10 bacteria were observed on glass when ATCC12228 were examined, under all the tested conditions, whereas larger clusters were observed when the bacteria were adhering on the $\mathrm{CH}_{3}$-terminated substrate. Slime was not observed, under all tested conditions, when the slime-negative strains were examined. Similar results were obtained when the slimenegative, ica-positive strain GRE2264 was examined (images not presented).

In order to quantitatively examine the effect of surface chemistry and shear rate on biofilm formation and PIA production, these two different patterns of adhesion: large clusters of bacteria on the $\mathrm{CH}_{3}$-terminated substrate (Figs. $2 \mathrm{a}, 2 \mathrm{~b}, 2 \mathrm{e}$ and $2 \mathrm{f}$ ) and isolated bacteria or small aggregates on the $\mathrm{OH}$-terminated one (Figs. $2 \mathrm{c}$ and $2 \mathrm{~d}$ ), were further examined by means of SCLM.

\section{Scanning confocal laser microscopy}

Table 3 presents the combined effect of surface chemistry and shear rate on biofilm formation and PIA production, as this was quantified by using the SCLM and the image analysis software: Image Pro Plus. The percentage (\%) of the material surface covered by biofilm, the biofilm thickness and the percentage of biofilm covered by PIA showed that the slime-positive bacterial strains presented similar adhesion trends; larger biofilms covered by PIA were formed on the $\mathrm{CH}_{3}$-terminated glass in comparison to the OH-terminated one $(p<0.01)$. As shown in Fig. 3 and Table 3, PIA production is significantly higher on the $\mathrm{CH}_{3}$-terminated substrates (Figs. $3 \mathrm{a}$ and $3 \mathrm{~b}$ ) than on the $\mathrm{OH}$-terminated ones (Figs. $3 \mathrm{c}$ and $3 \mathrm{~d})(p<0.01)$, when ATCC35984 was examined. Most slime production was observed $2 \mathrm{~h}$ after bacterial adhesion (Figs. 3a and $3 \mathrm{~b}$ ). Biofilm formation and PIA production were induced after $4 \mathrm{~h}$ of incubation into the PPFC for all the $\mathrm{CH}_{3}$-terminated substrates under the lower shear rate. 

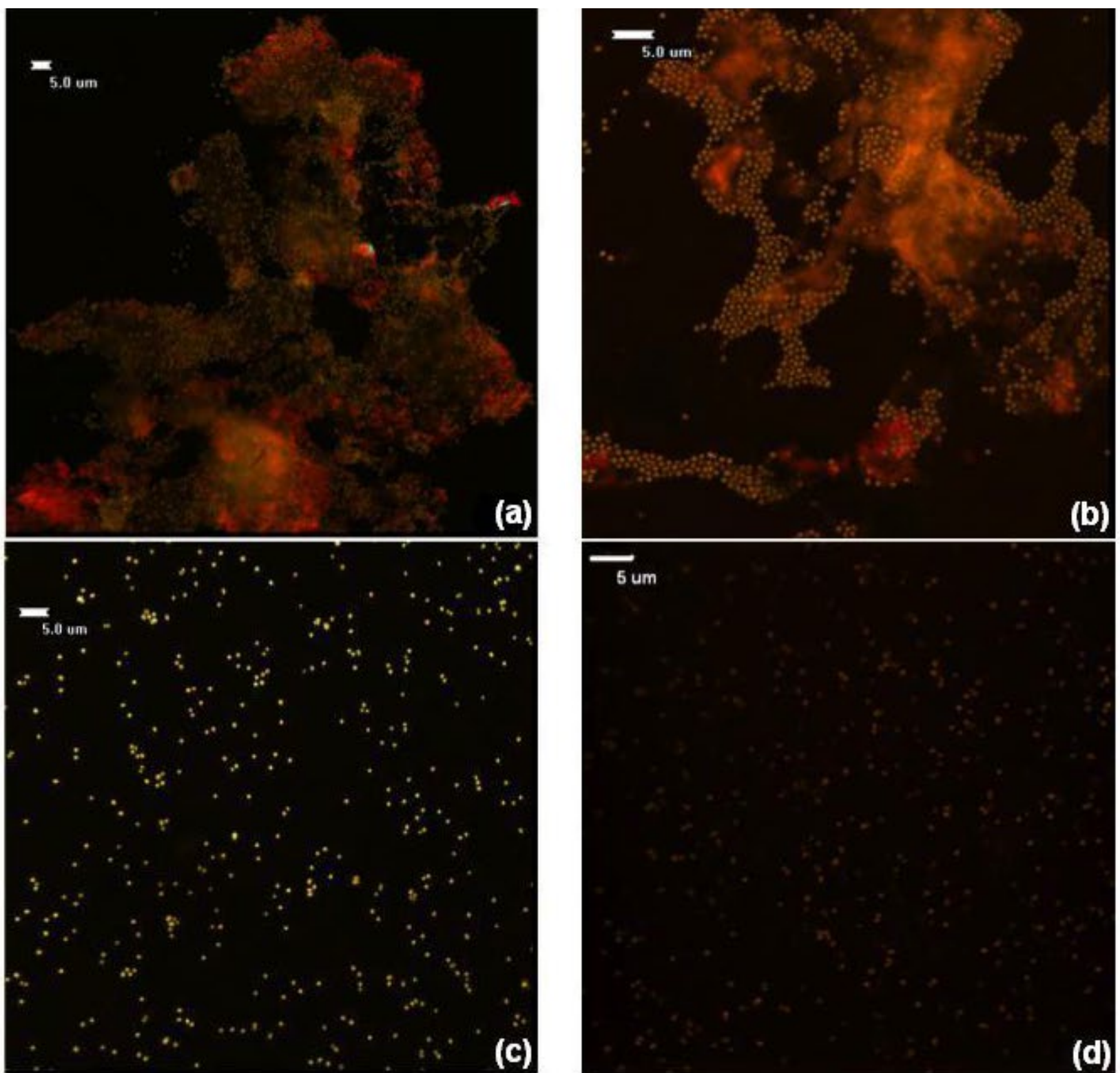

$$
5 \text { um }
$$
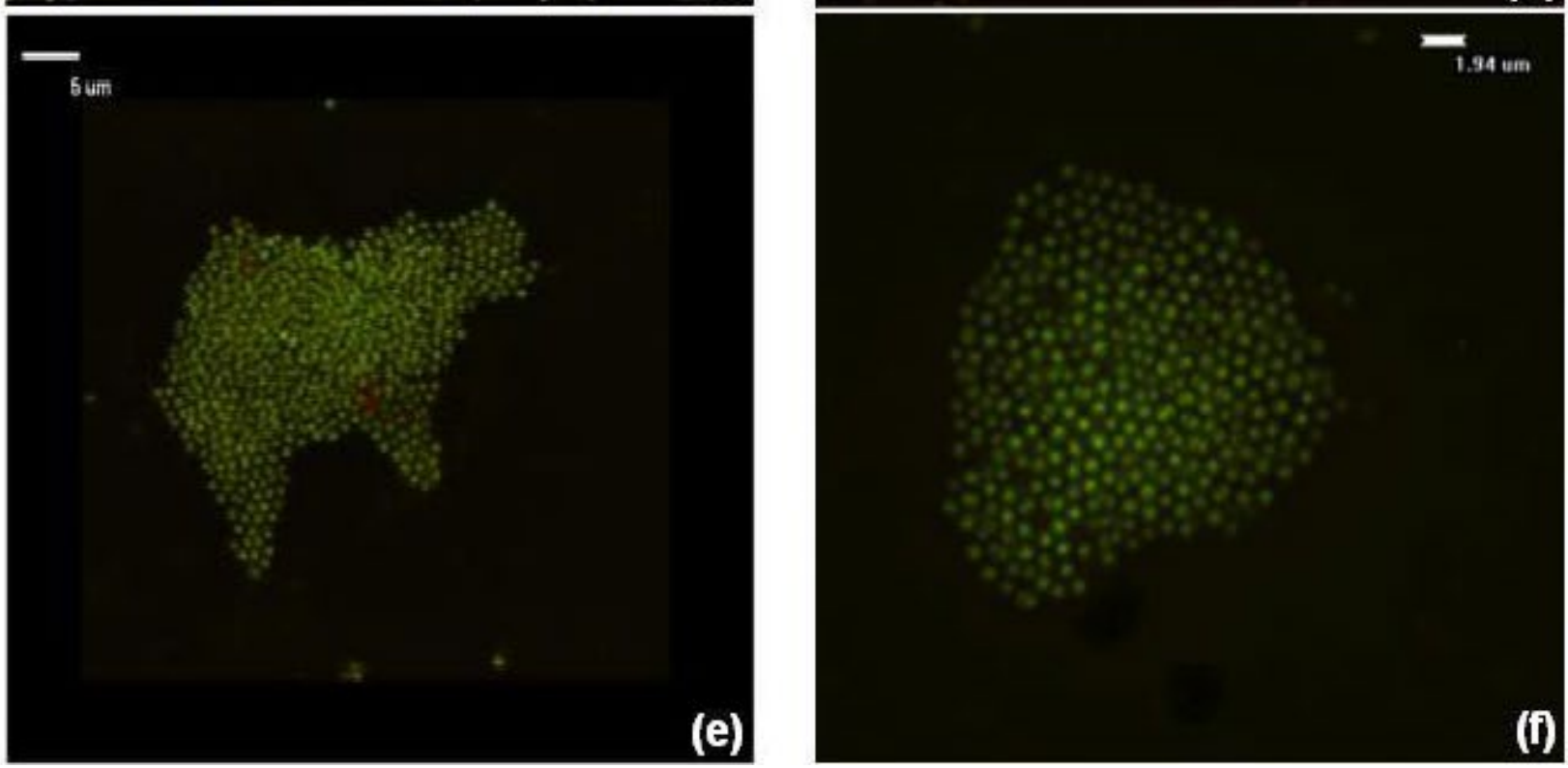

Fig. 3. SCLM images of ATCC35984 interacting with the $\mathrm{CH}_{3}$-terminated substrate under $50 \mathrm{~s}^{-1}$ (a) and 2,000 s-1 (b) two hours after adhesion, of ATCC35984 interacting with the OH-terminated substrate under $50 \mathrm{~s}^{-1}$ (c) and 2,000 s (d), two hours after adhesion and of ATCC12228 (e) and GRE2264 (f) interacting with the $\mathrm{CH}_{3}$-terminated substrate under $2,000 \mathrm{~s}^{-1}$, two hours after adhesion. Scale bars represent $5 \mu \mathrm{m}$ for images (a-e) and $1.94 \mu \mathrm{m}$ for image (f). 


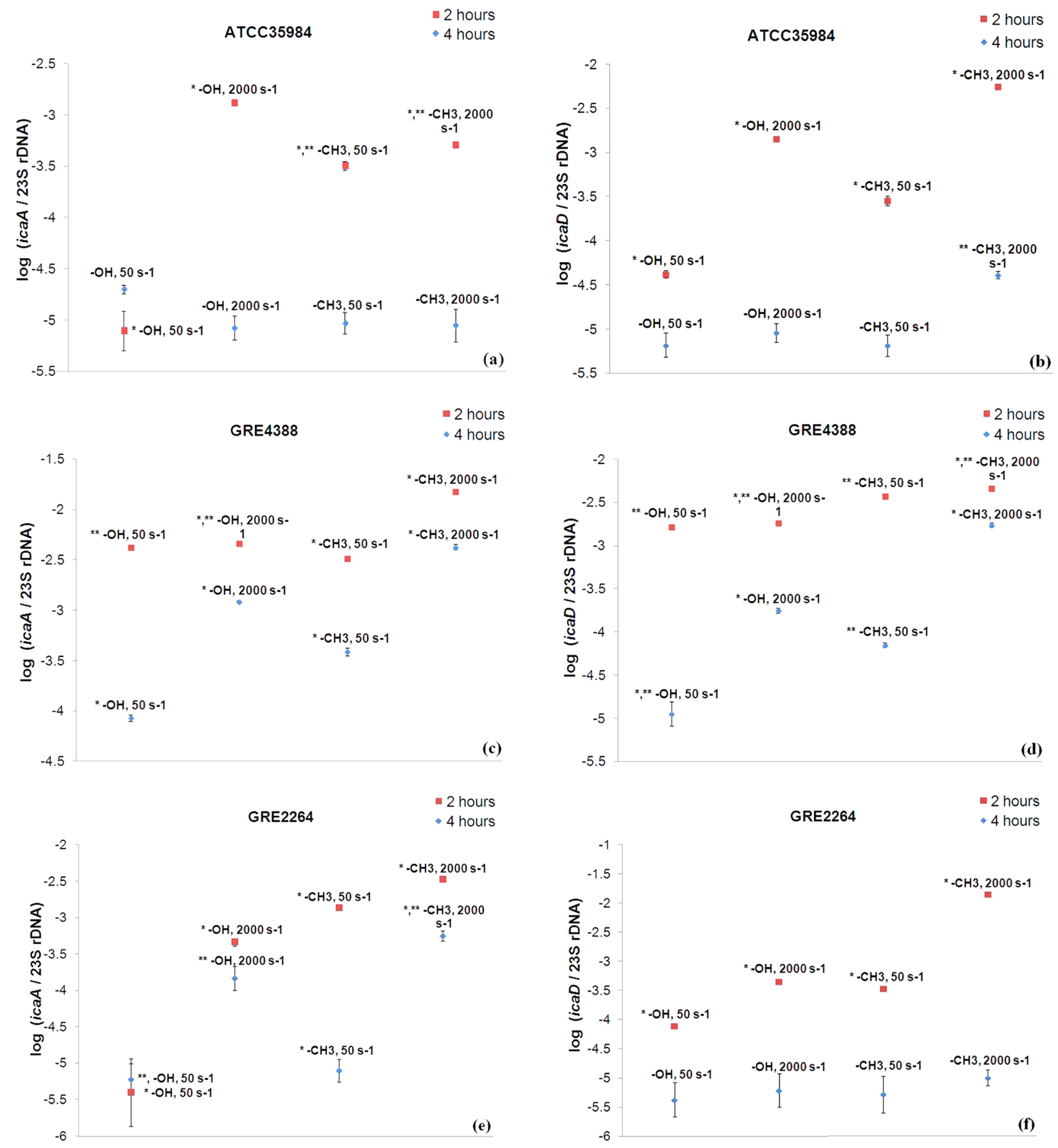

Fig. 4. Effect of shear rate and surface chemistry on adherent bacteria for strains: ATCC 35984 on $i c a A 2$ and $4 \mathrm{~h}$ after adhesion (a) and on icaD 2 and $4 \mathrm{~h}$ after adhesion (b); GRE4388 on icaA 2 and $4 \mathrm{~h}$ after adhesion (c) and on $i c a D 2$ and $4 \mathrm{~h}$ after adhesion (d); GRE2264 on icaA 2 and $4 \mathrm{~h}$ after adhesion (e) and on icaD 2 and $4 \mathrm{~h}$ after adhesion (f). Results are expressed as mean values and error bars indicate standard deviation $(n=3)$. ${ }^{*} p<0.001, * * p<0.05$, when the results for the same adhesion time are compared.

Similar results were obtained when GRE4388 was examined. Most slime was produced on the $\mathrm{CH}_{3}$-terminated substrates, but $4 \mathrm{~h}$ after adhesion, and not after 2 hours, as was the case for ATCC35984 (Table 3).

A decrease in the biofilm formation but an increase in PIA production, for the slime-positive bacterial strains, was observed when the shear rate increased from $50 \mathrm{~s}^{-1}$ to 2,000 s $\mathrm{s}^{-1}, 2 \mathrm{~h}$ after adhesion (Table 3 and Figs. $3 \mathrm{c}$ and $3 \mathrm{~d}$ ). However, after $4 \mathrm{~h}$, under the higher shear rate conditions, the quantity of PIA is lower than in $2 \mathrm{~h}(p<0.01)$, possibly due to detachment.
The lowest surface coverage by biofilm was calculated under the higher shear rate onto the $\mathrm{OH}$-terminated surface, for all bacterial strains and this was significantly different $(p<0.01)$, for all the possible combinations.

Under the aforementioned conditions, the clinical slime-positive strain (GRE4388) formed the largest biofilms, even in comparison to the reference slimepositive strain ATCC35984. However, GRE4388 produced less PIA than ATCC35984 $(p<0.05)$ (Table 3).

The reference slime-negative strain ATCC12228 presented similar values of biofilm formation (attached 
bacteria) on the $\mathrm{OH}$-terminated substrates, under both shear rates, as the reference ATCC35984. Higher values of attached bacteria on the $\mathrm{CH}_{3}$-terminated substrate were detected, under both shear rates, in comparison to ATCC35984 (Fig. 1).

The clinical slime-negative strain (GRE2264) presented the lowest biofilm formation (attached bacteria); in comparison to all other bacterial strains for all the possible combinations $(p<0.01)$.

For both slime-negative strains; ATCC12228 and GRE2264, no PIA production was observed, under all tested conditions (Figs. $3 \mathrm{e}$ and $3 \mathrm{f}$ and Table 3 ) and the percentage $(\%)$ of biofilm covered by PIA that is presented is due to non specific binding.

\section{ica Gene Expression}

The slime-negative reference strain ATCC12228 gave negative PCR results under all the tested conditions. For all the other tested bacterial strains, the expression levels of both $i c a A$ and $i c a D$ were much higher $2 \mathrm{~h}$ after adhesion than $4 \mathrm{~h}$ later, especially in the case of ATCC35984.

Reference strain ATCC35984 showed statistically significant higher expression of ica genes under the higher shear rate $2 \mathrm{~h}$ after adhesion to both materials $(p<0.001)$ (Figs. 4a and 4d). A statistically significant higher expression was observed for $i c a D$, under the higher shear rate, $2 \mathrm{~h}$ after adhesion to the $\mathrm{CH}_{3}$-terminated glass, in comparison to all the other samples (Fig. 4d).

The clinical slime-positive strain GRE4388 showed high expression of icaA on the $\mathrm{CH}_{3}$-terminated glass under the higher shear rate and of $i c a D$ on the $\mathrm{CH}_{3}$-terminated glass, under both shear rates (Figs. $4 \mathrm{~b}$ and $4 \mathrm{e})(p<0.001)$. The increase in shear rate increased the expression level of both ica genes to both materials.

The clinical slime-negative strain GRE2264 presented similar results as the other two strains, showing high expression of both genes $2 \mathrm{~h}$ after adhesion to the $\mathrm{CH}_{3}$ terminated glass, under the higher shear rate $(p<0.001)$ (Figs. 4c and 4f).

\section{Discussion}

In this study the combined effect of the surface chemistry and shear rate on four S. epidermidis strains adhesion, biofilm formation, PIA production and icaA and icaD expression was investigated. The relative contribution of physicochemical and hydrodynamic interactions on bacterial adhesion and specific genes expression was addressed by quantitative measurement of bacterial adhesion, slime production and gene expression on surfaces in laminar flow, as a function of fluid shear rate.

The adhesion of the four bacterial strains showed similar trends. All bacterial strains adhered significantly more to the $\mathrm{CH}_{3}$-terminated glass in comparison to the $\mathrm{OH}$-terminated one $(p<0.01)$ and produced biofilm on this substrate. The lowest number of attached bacteria was calculated under the higher shear rate onto the $\mathrm{OH}$ terminated surface, for all bacterial strains. The reference slime-negative strain ATCC12228 presented similar values of attached bacteria on the OH-terminated substrates, under both shear rates, as the reference slime-positive ATCC35984. Higher numbers of attached bacteria on the $\mathrm{CH}_{3}$-terminated substrate were calculated when compared with ATCC35984. Therefore, although ATCC12228 does not produce slime, it exhibited higher adhesion and biofilm formation ability, due probably to its surface characteristics and in particular due to its low polarity (Katsikogianni and Missirlis, 2010), meaning that PIA is not the only factor mediating bacterial adhesion to biomaterials and accumulation. This is in agreement with Mack's et al., observations that strains of $S$. epidermidis lacking icaADBC may also produce biofilm (Mack et al., 2007). Moreover, although Zhang et al. (2003) described ATCC12228 as non-biofilm-forming, they showed that it has the required genes for Aap and autolysin production, among others, and these are possible pathogenic factors that enable adhesion and accumulation.

Apart from the number of adherent bacteria, biofilm formation and slime production is another important parameter that affects bacterial pathogenicity. Even though bacterial strains were found in which biofilm formation is independent of PIA, in vivo models have shown that PIA contributes to virulence of $S$. epidermidis (Otto, 2012). Biofilms protect bacteria from antibiotics and immune mechanisms of the host, acting as a mechanical barrier (Otto, 2012).

SCLM and image analysis revealed that larger biofilms covered by more PIA were formed on the $\mathrm{CH}_{3}$-terminated glass in comparison with the $\mathrm{OH}$-terminated one, by the slime-positive strains. The clinical slime-positive strain GRE4388 produced larger biofilms than the reference slime-positive strain ATCC35984, but the later produced more PIA. The increase in shear rate increased PIA production, two hours after adhesion, for both $\mathrm{CH}_{3}$ - and $\mathrm{OH}$ - terminated substrates, meaning that both surface chemistry and shear conditions affect the phenotype of attached bacteria.

In order to investigate possible links between phenotypic responses and genetic activity of bacteria during bacteriamaterial interactions under shear conditions, assessment of $i c a A$ and $i c a D$ gene expression towards a part of $23 \mathrm{~S}$ rDNA was performed.

Both icaA and icaD seem to be influenced by the material surface chemistry and the shear conditions in a similar manner, with the expression rate of $i c a D / 23 \mathrm{SrDNA}$ being higher in comparison to icaA/23SrDNA for almost all the cases. This result might be related to the timing of bacterial harvesting, after 2 and 4 hours of incubation, eliciting that icaA is expressed at earlier stages.

Comparing the ability of the adherent bacteria to express ica genes, among the different strains, the highest ratio was observed for the clinical slime-positive strain (GRE4388). Cerca et al. (2005) also observed the straindependence of biofilm formation onto acrylic and glass surfaces among various $S$. epidermidis strains.

However, ATCC35984 produced more PIA in comparison to the other strains, although GRE4388 showed higher gene expression. This may be explained by the time dependence of gene expression, or that the reference strain responds less to the different biomaterials perhaps because it has lost the ability to sense a surface, indicating 
the importance to use clinical strains in such experiments (Nuryastuti et al., 2011). According to our results the highest expression rates of ica genes among adherent bacteria was observed after two hours of adhesion, in comparison with the four hours. This could mean that for such a small system, as the flow chambers that were used in this study, genes are expressed even earlier. A trial that was done to examine gene expression after half an hour did not give results, as the number of attached bacteria was low and did not allow enough RNA isolation. Therefore, it may be possible that in the case of ATCC35984 ica genes are expressed earlier than in the case of GRE4388 giving more PIA production for the reference slime-positive strain, as this was observed by the scanning confocal laser and the scanning electron microscopes. Early high transcription of icaA has also been reported in a study using stainless steel (Kajiyama et al., 2009) and during an in vitro foreignbody colonisation model (Vandecasteele et al., 2004). In a study performed under static conditions, analysis of icaA expression on the various materials showed that while polyethylene showed the highest expression of the icaA for all clinical isolates, it allowed only marginal biofilm growth, while polymethylmethacrylate and stainless steel showed the more extensive biofilm formation, but did not have the highest icaA expression (Nuryastuti et al., 2011). In our case, the effect of the surface chemistry on icaA and icaD genes expression was observed for both slime-positive strains, ATCC35984 and GRE4388. Additionally, the slime-negative GRE2264 strain showed high expression of $i c a$ genes when bacteria were interacting with the $\mathrm{CH}_{3}$-terminated glass substrate, two hours after adhesion. This is in agreement with the work of Khalichi et al. (2009) that showed increased expression levels of glucosyltransferase B $(g t f B)$, a gene that is involved in Streptococcus mutans biofilm formation, for bacterial cells that came in contact with triethylene glycol derived from dental composite resins.

Trying to explain the adhesion of the four bacterial strains to the various substrates, the biofilm formation, the PIA production and the ica gene expression, we considered that the changes in the chemical structure that took place during the organosilane deposition have to be the important parameters. The implementation of the "LW-AB" Thermodynamic approach allowed for the investigation of how the phenotypic and genotypic responses of the various bacterial strains are correlated not only with the $\gamma_{S}^{L W-A B}$, and its apolar $\left(\gamma_{s}^{L W}\right)$ and polar $\left(\gamma_{S}^{A B}\right)$ components, but also with the electron-donor $\left(\gamma_{s}^{-}\right)$and the electron-acceptor $\left(\gamma_{S}^{+}\right)$character of the substratum surfaces as well.

Regression analysis of these data revealed that all the parameters related to bacterial adhesion; number, biofilm formation, PIA production and gene expression were negatively correlated with the $\gamma_{s}^{L W-A B}$ and its polar $\left(\gamma_{S}^{A B}\right)$ component $(p<0.001)$, whereas there was not significant correlation with its apolar $\left(\gamma_{s}^{L W}\right)$ component. Concerning the $\gamma_{s}^{-}$and the $\gamma_{S}^{+}$character of the substratum surfaces, the regression analysis revealed that all the parameters were negatively correlated with $\gamma_{s}^{-}(p<0.001)$, but they were not significantly correlated with $\gamma_{s}^{+}$, for all the bacterial strains. Therefore, the electron donor character of the substratum surface is one of the material properties that control bacterial adhesion. In particular, an increase in $\gamma_{s}^{-}$decreases bacterial adhesion and gene expression $(p<0.001)$. These results are in agreement with Liu's et al. (2007) results, which showed that the attachment of $S$. epidermidis to non-protein coated surfaces was compatible with the thermodynamic theory.

Our literature survey revealed controversies concerning the effect of the surface free energy and its polar component on adhesion. In our previous study (Katsikogianni et al., 2008) we observed that adhesion of $S$. epidermidis onto $\mathrm{He}$ and $\mathrm{He} / \mathrm{O}_{2}$ treated PET was reduced in comparison to PET, due to the increase in the surface free energy and polar component, whereas the ageing time and the consequent decrease in the surface free energy and polar component favoured bacterial adhesion. Moreover, Balazs et al. (2003) observed that $\mathrm{O}_{2}$ plasma treated $\mathrm{PVC}$ reduced Pseudomonas aeruginosa adhesion as much as $70 \%$, whereas, in another study, S. epidermidis adhesion was increased by $\mathrm{O}_{2}$ plasma treated polystyrene (Morra and Cassinelli, 1996).

Moreover, the zeta potential of the substratum surfaces is another parameter that significantly influences bacterial adhesion. Since the four bacterial strains appeared negatively charged, when bacteria were suspended in $0.9 \% \mathrm{NaCl}$, all the bacterial adhesion parameters were negatively correlated with the materials' zeta potential. For this reason, adhesion was found to be lowest onto the $\mathrm{OH}$-terminated glass that appeared negatively charged in the same solution. This is in agreement with the results of Sharp and Dickinson (2005).

As far as the predictability of the XDLVO theory, the results revealed that the number of adherent bacteria was negatively correlated with the total interaction energy $U_{d=1 n m}^{X D L V O}$ and therefore it predicts in a qualitative manner the combined effect of the $\mathrm{LW}$, the EL and the AB interactions between the bacteria and the substratum surfaces as a function of distance. These results are in agreement with those of Meiders et al. (1995).

The flow conditions and the associated hydrodynamic forces strongly influence the number of attached bacteria. In particular, it was observed that the increase in shear rate decreased the number of adherent bacteria to both $\mathrm{CH}_{3}$ - and $\mathrm{OH}$ - terminated substrates, for all the four tested bacterial strains. The lowest number of attached bacteria was calculated under the higher shear rate onto the $\mathrm{OH}$ terminated surface, for all bacterial strains.

These results are in agreement with those of Bayoudh et al. (2005) and Nuryastuti et al. (2008), who observed that bacterial adhesion strength measurements were in agreement with the adhesion free energy calculations. In contrast Finlay et al. (2002) observed that although the highest number of Enteromorpha zoospores adhered to the less polar SAMs surface, which is in accordance with the thermodynamic theory, at high shear stress (56 Pa) zoospores detached more easily from the less polar SAMs than from the polar ones.

Moreover, this study showed that the increase in shear rate greatly influenced not only the number of adherent bacteria, but the expression levels of icaA and icaD genes as well. In previous studies, there is evidence that bacteria in biofilm can respond to shear by altering their 
morphology, size, density growth rate and metabolism (Liu and Tay, 2001; 2002). Under higher shear rates the resulting biofilm was found to be denser and thinner, while higher dehydrogenase activity and lower growth yield were obtained when the shear rate was raised. The reduced growth yield, together with the enhanced catabolic activity, suggests that a dissociation of catabolism from anabolism may occur at high shear rates. Therefore, a biological phenomenon, besides a simple physical effect, may underline the observed relation between the shear rate and the resulting biofilm structure and performance.

Although it is known that both prokaryotic and eukaryotic cells are capable of sensing mechanical forces and converting them into biological signals via mechanotransduction mechanisms, this process is relatively less understood (Vogel and Sheetz, 2006; Kim et al., 2009). In the case of bacteria, it has been observed that shear stress strengthens $E$. coli attachment to red blood cells through biological interactions that are enhanced by mechanical force pulling a ligand-receptor complex apart, and are known as "catch bonds" (Thomas et al., 2002). One compelling model for these force-enhanced interactions proposes that conformation of the ligand-binding pocket in the receptor protein is allosterically linked to the quaternary configuration of the receptor domains (Sokurenko et al., 2008).

According to our knowledge though, no study has been published so far on the effect of shear rates, similar to the ones found in vivo, on bacterial gene expression. Only the effect of low-shear modelled microgravity conditions on Salmonella typhimurium function has been examined so far, where increased virulence, resistance to environmental stresses and global changes in gene expression were identified (Wilson et al., 2007).

However, fluid shear stress, which occurs naturally in a variety of physiological conditions, is one of the most important mechanostimuli. Although it has been shown that numerous cellular functions are regulated by shear stress (Jacobs et al., 1998; Shive et al., 2000; Yamamoto et $a l ., 2005)$, in the case of bacteria much research has been conducted so far to investigate cellular responses to soluble biochemical factors, such as growth factors and bacterial density (Baca-Delancey et al., 1999), salts, ethanol, iron, nutrient-limited factors and heat (Fitzpatrick et al., 2002; O'Gara, 2007), and to low-energy pulsed ultrasonic simulation (Ishibashi et al., 2010).

In this study it was observed that the increase in shear rate significantly increased ica gene expression for both substrates and adhesion times $(p<0.01)$. This study therefore not only confirms what others have shown about how bacterial adhesion is influenced by the physicochemical characteristics of the bacterium, the substratum and the fluid interface. It also shows that the combination of interactions between the bacteria and the substrata, such as electrostatic, Lifhsitz - van der Walls and acid base, under the presence of shear stress, significantly affects bacterial ica gene expression.

$\mathrm{OH}$ and $\mathrm{CH}_{3}$ - groups are present on metallic, ceramic and polymeric surfaces, as well as on biological substrates and were chosen because their physicochemical properties are significantly different. The results of the present study suggest that in the case of the $\mathrm{CH}_{3}$ SAM bacterial adhesion and biofilm formation, partially by the expression of ica genes, seem to be enabled by the attractive colloidal forces at contact, as well as by the presence of trapped nanobubbles at the less polar substrate (Seddon and Lohse, 2011). The strong repulsive colloidal forces in the case of the $\mathrm{OH}$-terminated glass seem to inhibit not only bacterial adhesion but slime production as well, due possibly to reduced ica gene expression.

Therefore, these results suggest that the incorporation of $\mathrm{OH}$ groups and the subsequent increase of the surface energy, the polar $\left(\gamma_{S}^{A B}\right)$ component, the electron-donor $\left(\gamma_{S}^{-}\right)$character and the negative charge of the proposed as a biomaterial substrate can decrease both the bacterial adhesion and the biofilm formation. In this direction, the use of chemicals treatments or plasma for the incorporation of $\mathrm{OH}$ groups, or the use of various phenols and phenolic acids, quinones, flavonoids, alkanoids, lectins or polypeptides, that are found in various natural extracts and have been shown to exert a broad spectrum of biological activities (Cowan, 1999), including antimicrobial properties, could be useful solutions for the reduction of the biomaterial associated infections. Furthermore, the effect of shear stress on the changes in gene expression of adhering bacteria is another parameter that should be taken into consideration for the design of biomaterials, as the increase in shear rate significantly increased ica gene expression for both substrates and adhesion times.

A limitation of the present study is that the reactivity of other genes contributing to $S$. epidermidis adhesion and biofilm formation under the same conditions has not been tested.

\section{Conclusion}

This study was conducted with a collection of reference and clinical $S$. epidermidis strains with different phenotypes and genotypes, utilising two shear rates and two surface functionalities, in order to investigate how surface chemistry and hydrodynamic conditions influence biofilm formation and ica gene expression. The results showed that both parameters significantly influence both biofilm formation and the expression of ica locus. The combination of both conventional phenotypic analysis, using SEM and SCLM, and genotypic analysis, using the relative reverse transcription polymerase chain reaction (RT-PCR), offers the potential to explore the links between phenotypic responses to bacteria-material interactions and gene expression profile alterations, under dynamic conditions. Bacterial adhesion as well as slime production and biofilm formation were much higher on the $\mathrm{CH}_{3}$-teminated glass than on the $\mathrm{OH}$-terminated one, for the slime-positive $S$. epidermidis strains, and these were in agreement with the increased icaA and icaD gene expression levels for the bacteria adhering to the $\mathrm{CH}_{3}$-terminated substrate, especially under the higher shear rate. These observations indicate that the analysis of gene expression, along with the use of appropriate microscopies may provide a more 
comprehensive and integrated insight into the bacterialmaterial interactions, but also introduce novel bio-assays towards biocompatibility assessment.

\section{Acknowledgments}

This project was partially funded by the programme: INTERREG IIIA: GREECE - ITALY "Establishment of a Multidisciplinary Scientific Network for the development and application of Advanced Biomaterials" 2006-2008.

\section{References}

An YH, Friedman RJ (1997) Laboratory methods for studies of bacterial adhesion. J Microbiol Meth 30: 141152.

Arciola CR, Campoccia D, Cervellati M, Donati E, Montanaro L (2002) Detection of slime production by means of an optimised Congo red agar plate test based on a colourimetric scale in Staphylococcus epidermidis clinical isolates genotyped for ica locus. Biomaterials 23: 4233-4239.

Baca-Delancey RR, South MMT, Ding X, Rather PN (1999) Escherichia coli genes regulated by cell-to-cell signalling. Proc Natl Acad Sci USA 96: 4610-4614.

Balazs DJ, Triandafillu K, Chevolot Y, Aronsson B-O, Harms H, Descouts P, Mathieu HJ (2003) Surface modification of PVC endotracheal tubes by oxygen glow discharge to reduce bacterial adhesion. Surf Interf Anal 35: 301-309.

Bayoudh S, Ponsonnet L, Ben Ouada H, Bakhrouf A, Othmane A (2005) Bacterial detachment from hydrophilic and hydrophobic surfaces using a microjet impingement. Coll Surf A: Physicochem Eng Aspects 266: 160-167.

Becker P, Hufnagle W, Peters G, Herrmann M (2001) Detection of different gene expression in biofilm-forming versus planktonic populations of Staphylococcus aureus using micro-representational-difference analysis. Appl Environ Microbiol 67: 2958-2965.

Boks NP, Kaper HJ, Norde W, Busscher HJ, van der Mei HC (2008a) Residence time dependent desorption of Staphylococcus epidermidis from hydrophobic and hydrophilic substrata. Colloids Surf B: Biointerf 67: 276278.

Boks NP, Norde W, van der Mei HC, Busscher HJ (2008b) Forces involved in bacterial adhesion to hydrophilic and hydrophobic surfaces. Microbiology 154: 3122-3133.

Campoccia D, Montanaro L, Spezialec P, Arciola CR (2010) Antibiotic-loaded biomaterials and the risks for the spread of antibiotic resistance following their prophylactic and therapeutic clinical use. Biomaterials 31: 6363-6377.

Cerca N, Pier GB, Vilanova M, Oliveira R, Azeredo J (2005) Quantitative analysis of adhesion and biofilm formation on hydrophilic and hydrophobic surfaces of clinical isolates of Staphylococcus epidermidis. Res Microbiol 156: 506-514.

Chini V, Foka A, Dimitracopoulos G, Spiliopoulou I (2007) Absolute and relative real-time PCR in the quantification of tst gene expression among methicillin- resistant Staphylococcus aureus: evaluation by two mathematical models. Lett Appl Microbiol 45: 479-484.

Costerton JW, Stewart PS, Greenberg EP (1999) Bacterial biofilms: a common cause of persistent infections. Science 284: 1318-1322.

Cowan MM (1999) Plant products as anticrobial agents. Clin Microbiol Rev 12: 564-582.

Davies DG, Geesey GG (1995) Regulation of the alginate biosynthesis gene algC in Pseudomonas aeruginosa during biofilm development in continuous culture. Appl Environ Microbiol 61: 860-867.

Faucheux N, Schweiss R, Lutzow K, Werner C, Groth $\mathrm{T}$ (2004) Self-assembled monolayers with different terminating groups as model substrates for cell adhesion studies. Biomaterials 25: 2721-2730.

Finlay JA, Callow ME, Ista LK, Lopez GP, Callow JA (2002) The influence of surface wettability on the adhesion strength of settled spores of the green alga Enteromorpha and the diatom Amphora. Integr Comp Biol 42: 1116-1122.

Fitzpatrick F, Humphreys H, Smythy E, Kennedy CA, O'Gara JP (2002) Environmental regulation of biofilm formation in intensive care unit isolates of Staphylococcus epidermidis. J Hospital Infect 42: 212-218.

Fluckiger U, Ultrich M, Steinhuber A, Döring G, Mack D, Landmann R, Goerke C, Woltz C (2005) Biofilm formation, icaADBC transcription and Polysaccharide Intercellular Adhesin synthesis by staphylococci in a device-related infection model. Infect Immun 73: 18111819.

GerkeC,KraftA, SussmuthR, SchweitzerO, GotzF(1998) Characterization of the $\mathrm{N}$-acetylglucosaminyltransferase activity involved in the biosynthesis of the Staphylococcus epidermidis polysaccharide intercellular adhesin. J Biol Chem 273: 18586-18593.

Goldsmith HL, Turitto VT (1986) Reological aspects of thrombosis and haemostasis: Basic principles and applications. Thromb Haemostas 55: 415-435.

Heilmann C, Schweitzer O, Gerke C, Vanittanakom N, Mack D, Gotz F (1996) Molecular basis of intercellular adhesion in the biofilm-forming Staphylococcus epidermidis. Molec Microbiol 20:1083-1091.

Ishak MA, Groschel DHM, Mandell GL, Wenzel RP (1985) Association of slime with pathogenicity of coagulase-negative staphylococci causing nosocomial septicenmia. J Clin Microbiol 22:1025-1029.

Ishibashi K, Shimada K, Kawato T, Kaji S, Maeno M, Sato S, Ito K (2010) Inhibitory effects of low-energy pulsed ultrasonic stimulation on cell surface protein antigen $\mathrm{C}$ through heat shock proteins GroEL and DnaK in Streptococcus mutans. Appl Environm Microbiol 76:751756.

Jacobs C, Yellowley C, Davis B, Zhou Z, Cimbala J, Donahue H (1998) Differential effect of steady versus oscillating flow on bone cells. J Biomech 31: 969-976.

Kajiyama S, Tsurumoto T, Osaki M, Yanagihara K, Shindo H (2009) Quantitative analysis of Staphylococcus epidermidis biofilm on the surface of biomaterial. J Orthop Sci 14: 769-775.

Katsikogianni MG, Missirlis YF (2010) Interactions of bacteria with specific biomaterial surface chemistries under flow conditions. Acta Biomater 6: 1107-1118. 
Katsikogianni M, Spiliopoulou I, Dowling DP, Missirlis YF (2006) Adhesion of slime producing Staphylococcus epidermidis strains to PVC and diamond-like carbon/silver/ fluorinated coatings. J Mater Sci Mater Med 17: 679-689.

Katsikogianni M, Amanatides E, Mataras DS, Missirlis YF (2008) Staphylococcus epidermidis Adhesion to He, $\mathrm{He} / \mathrm{O}_{2}$ plasma treated $\mathrm{PET}$ films and aged materials: Contributions of surface free energy and shear rate. Colloids and Surf B: Biointerf 65:257-268.

Khalichi P, Singh J, Cvitkovitch DG, Santerre JP (2009) The influence of triethylene glycol derived from dental composite resins on the regulation of Streptococcus mutans gene expression. Biomaterials 30: 452-459.

Kim D-H, Wong PK, Park J, Levchenko A, Sun Y (2009) Microengineered platforms for cell mechanobiology. Annu Rev Biomed Eng 11: 203-233.

Kontos F, Petinaki E, Spiliopoulou I, Maniati M, Maniatis AN (2003) Evaluation of a novel method based on PCR analysis of the tuf gene for the identification of Staphylococcus species. J Microbiol Meth 55: 465-469.

Liu Y, Tay J-H (2001) Metabolic response of biofilm to shear stress in fixed-film culture. J Appl Microbiol 90: 337-342.

Liu Y, Tay J-H(2002) The essential role of hydrodynamic shear force in the formation of biofilm and granular sludge. Water Res 36: 1653-1665.

Liu Y, Strauss J, Camesano TA (2007) Thermodynamic investigation of Staphylococcus epidermidis interaction with protein-coated substrata. Langmuir 23: 7134-7142.

Mack D, Davies AP, Harris LG, Rohde H, Horstkotte MA, Knobloch JK (2007) Microbial interactions in Staphylococcus epidermidis biofilms. Anal Bioanal Chem 387: 399-408.

Meiders JM, van der Mei HC, Buccher HJ (1995) Deposition efficiency and reversibility of bacterial adhesion under flow. J Colloid Interface Sci 176: 329-341.

Morra M, Cassinelli C (1996) Staphylococcus epidermidis adhesion to films deposited from hydroxyethylmethacrylate plasma. J Biomed Mater Res 31: 149-155.

Mrksich M (1997) Using self-assembled monolayers to understand the biomaterials interface. Curr Opin Colloid Int Sci 2: 83-88.

Nejadnik MR, van der Mei HC, Busscher HJ, Norde W (2008) Determination of the shear force at the balance between bacterial attachment and detachment in weakadherence systems, using a flow displacement chamber. Appl Environm Microbiol 74: 916-919.

Nuryastuti T, Krom BP, Aman AT, Busscher HJ,van der Mei HC (2011) Ica-expression and gentamicin susceptibility of Staphylococcus epidermidis biofilm on orthopedic implant biomaterials. J Biomed Mat Res A 96: 365-371.

O'Gara JP (2007) ica and beyond: biofilm mechanisms and regulation in Staphylococcus epidermidis and Staphylococcus aureus. FEMS Microbiol Lett 270: 179188.

Otto M (2012) Molecular basis of Staphylococcus epidermidis infections. Semin Immunopathol 34: 201-214.
Pfaffl MW (2004) Quantification strategies in realtime PCR in: A-Z of quantitative PCR (Bustin SA ed). International University Line (IUL), La Jolla, pp 87-112.

Popat KC, Eltgroth M, LaTempa TJ, Grimes CA, Desai TA(2007) Decreased Staphylococcus epidermidis adhesion and increased osteoblast functionality on antibiotic-loading titania nanotubes. Biomaterials 28: 4880-4888.

Prigent-Combaret C, Vidal O, Dorel C, Lejeune P (1999) Abiotic surface sensing and biofilm-dependent regulation of gene expression in Escherichia coli. J Bacteriol 181: 5993-6002.

Razatos A, Ong Y-L, Sharma MM, Georgiou G (1998) Molecular determinants of bacterial adhesion monitored by atomic force microscopy. Proc Natl Acad Sci USA 95: 11059-11064.

Rohde H, Frankenberger S, Zähringer U, Mack D (2010) Structure, function and contribution of polysaccharide intercellular adhesin (PIA) to Staphylococcus epidermidis biofilm formation and pathogenesis of biomaterialassociated infections. Eur J Cell Biol 89: 103-111.

Sambrook J, Fritsch EF, Maniatis T (1989). Isolation of total RNA from mammalian cells in: Molecular Cloning a Laboratory Manual, 2nd ed. Vol 1 (Nolan C ed). Cold Spring Harbor Laboratory Press, New York, pp 7.6-7.9.

Scheuerman TR, Camper AK, Hamilton MA (1998) Effects of substratum topography on bacterial adhesion. J Col Interf Sci 208: 23-33.

Seddon JRT, Lohse D (2011) Nanobubbles and micropancakes: gaseous domains on immersed substrates. J Phys: Condens Matter 23: 133001-133023.

Sharp JM, Dickinson RB (2005) Direct evaluation of DLVO theory for predicting long-range forces between a yeast cell and a surface. Langmuir 21: 8198-8203.

Shive M, Salloum M, Anderson J (2000) Shear stressinduced apoptosis of adherent neutrophils: a mechanism for persistence of cardiovascular device infections. Proc Natl Acad Sci USA 97: 6710-6715.

Silver JH, Lin J-C, Lim F, Tegoulia VA, Chaudhury MK, Cooper SL (1999) Surface properties and hemocompatibility of alkyl-siloxane monolayers supported on silicone rubber: effect of alkyl chain length and ionic functionality. Biomaterials 20: 1533-1543.

Sokurenko EV, Vogel V, Thomas WE (2008) Catch bond mechanism of force-enhanced adhesion: counterintuitive, elusive but... widespread? Cell Host Microbe 16: 314-323.

Stavridi M, Katsikogianni M, Missirlis YF (2003) The influence of surface patterning and/or sterilization on the haemocompatibility of polycaprolactones. Mater Sci Eng C 23: 359-365.

Strathmann M, Wingender J, Flemming H-C (2002) Application of fluorescently labeled lectins for the visualization and biochemical characterization of polysaccharides in biofilms of Pseudomonas aeruginosa. J Microbiol Methods 50: 237-248.

Sugimura H, Hozumi A, Kameyama T, Takai O (2002) Organosilane self-assembled monolayers formed at the vapour/solid interface. Surf Interface Anal 34: 550-554. 
Thomas W, Trintchina E, Forero M, Vogel V, Sokurenko E (2002) Bacterial adhesion to target cells enhanced by shear force. Cell 109: 913-923.

Truong VK, Lapovok R, Estrin YS, Rundell S, Wang JY, Fluke CJ, Crawford RJ, Ivanova EP (2010) The influence of nano-scale surface roughness on bacterial adhesion to ultrafine-grained titanium. Biomaterials 31: 3674-3683.

Tyler BJ, Ratner BD, Castner DG, Briggs D (1992) Variations between Biomer lots. I. Significant differences in the surface chemistry of two lots of a commercial poly(urethane). J Biomed Mater Res 26: 273-289.

Van Oss CJ, Good RJ, Chaudhury MK (1986) The role of van der Waals forces and hydrogen bonds in hydrophobic interactions between biopolymers and low energy surfaces. J Colloid Interface Sci 111: 378-390.

Vandecasteele SJ, Peetermans WE, Merckx R, Van Eldere J (2003) Expression of biofilm-associated genes in Staphylococcus epidermidis during in vitro and in vivo foreign body infections. J Infect Dis 188: 730-737.

Vandecasteele SJ, Peetermans WE, Carbonez A, Van Eldere J (2004) Metabolic activity of Staphylococcus epidermidis is high during initial and low during late experimental foreign-body infection. J Bacteriol 186: 2236-2239.

Vogel V, Sheetz M (2006) Local force and geometry sensing regulate cell function. Nature Rev 7: 265-275.

Vuong C, Kocianova S, Voyich JM, Yao Y, Fischer ER, DeLeo FR, Otto M (2004) A crucial role for exopolysaccharide modification in bacterial biofilm formation, immune evasion, and virulence. J Biol Chem 279: 54881-54886.

Wang IW, Danilich M, Anderson J, Marchant RE (1995) Adhesion of Staphylococcus epidermidis to biomedical polymers: contributions of surface thermodynamics and hemodynamic shear conditions. J Biomed Mater Res 29: 485-493.

Wasserman SR, Tao Y-T, Whitesides GM (1989) Structure and reactivity of alkysiloxane monolayer formed by reaction of alkyl trichlorosilane on silicon substrate. Langmuir 5: 1074-1087.

Wiencek KM, Fletcher M (1995) Bacterial adhesion to hydroxyl- and methyl-terminated alkanethiol selfassembled monolayers. J Bacteriol 177: 1959-1966.

Wilson JW, Ott CM, Höner zu Bentrup K, Ramamurthy R, Quick L, Porwollik S, Cheng P, McClelland M, Tsaprailis G, Radabaugh T, Hunt A, Fernandez D, Richter E, Shah M, Kilcoyne M, Joshi L, Nelman-Gonzalez M, Hing S, Parra M, Dumars P, Norwood K, Bober R, Devich J, Ruggles A, Goulart C, Rupert M, Stodieck L, Stafford P, Catella L, Schurr MJ, Buchanan K, Morici L, McCracken J, Allen P, Baker-Coleman C, Hammond T, Vogel J, Nelson R, Pierson DL, Stefanyshyn-Piper HM, Nickerson CA (2007) Space flight alters bacterial gene expression and virulence and reveals a role for global regulator Hfq. Proc Natl Acad Sci USA 104: 16299-16304.

Yamamoto K, Sokabe T, Watabe T, Miyazono K, Yamashita JK, Obi S, Ohura N, Matsushita A, Kamiya A, Ando J (2005) Fluid shear stress induces differentiation of Flk-1-positive embryonic stem cells into vascular endothelial cells in vitro. Am J Physiol Heart Circ Physiol 288: H1915-H1924.

Zhang Y-Q, Ren S-X, Li H-L, Wang Y-X, Fu G, Yang J, Qin Z-Q, Miao Y-G, Wang W-Y, Chen R-S, Shen Y, Chen Z, Yuan Z-H, Zhao G-P, Qu D, Danchin A, Wen Y-M (2003) Genome-based analysis of virulence genes in a non-biofilm-forming Staphylococcus epidermidis strain (ATCC 12228). Mol Microbiol 49: 1577-1593.

\section{Discussion with Reviewers}

Reviewer I: Is the transfer of cultures from vegetable broths and log phase growth instantly to minimal media ( $0.9 \%$ saline) a problem for preserving the bacterial phenotype during subsequent flow experiments? One would think that constant media adjustments stresses these cultures' properties.

Authors: Staphylococci are among the most resistant bacteria that can grow in a wide temperature range (10$45^{\circ} \mathrm{C}$ ), in $\mathrm{NaCl}$ (up to $7.5 \%$ ) and in minimal media. So this switch from the culture medium to normal saline had no effect on bacterial viability. As far as the bacterial phenotype, this may be altered as it has been shown in the study of Prigent-Combaret et al. (1999) (text reference) that $\beta$-galactosidase specific activity was reduced by the increase in $\mathrm{NaCl}$ concentration from 0 to $0.3 \mathrm{M}$. However, the bacterial suspension was always prepared under the same conditions for all the experiments performed in this study and therefore the observed phenotypic responses and the gene expression profile alterations were considered as the result of the bacteria-material interactions under dynamic conditions.

Reviewer II: How can you be sure that SAM layers are homogeneous, how can that be proven?

Authors: Detailed surface analysis is the only way to proof that a surface is homogenous. As detailed in this and our previous publication (Katsikogianni and Missirlis, 2010, text reference), SAMs prepared by the vapour method - and not by immersion are smooth and homogenous substrates, as the contact angle measurements, the XPS and the AFM showed.

Reviewer II: How can I see slime formation in the SEM pictures?

Authors: According to Alhede et al. (2012) (additional reference), no single method exists at present time for visualising the true architecture of the biofilm matrix. The Cryo-SEM and the environmental-SEM techniques seem to be more suited, because they appear to leave the matrix unaffected. However, the problem with these techniques is the poor resolution and hence limited magnification when compared to conventional SEM. The conventional SEM together with the scanning confocal laser microscopy (SCLM) provides good information on spatial structure, as the SCLM shows better the slime, but its resolution is lower than this of the SEM. However, the dehydration preparative step may leave the bacteria quite exposed. Still on the SEM images, the slime and the adhesins that were 
produced could be detected and the results presented by the two microscopes were in good agreement.

Therefore, no single method reveals the true nature of the biofilm, but if combined, the image data from the different methods are better able to predict the true architecture of the matrix and that what was attempted in this study.

\section{Additional Reference}

Alhede M, Qvortrup K, Liebrechts R, Høiby N, Givskov M, Bjarnsholt T (2012) Combination of microscopic techniques reveals a comprehensive visual impression of biofilm structure and composition. FEMS Immunol Med Microbiol 65: 335-342. 